\title{
DEVELOPMENT, STRUCTURE, AND TRANSFORMATION: SOME EVIDENCE ON COMPARATIVE ECONOMIC GROWTH
}

\author{
Gordon C. McCord \\ Jeffrey D. Sachs \\ Working Paper 19512 \\ http://www.nber.org/papers/w19512
NATIONAL BUREAU OF ECONOMIC RESEARCH
1050 Massachusetts Avenue
Cambridge, MA 02138
October 2013

The views expressed herein are those of the authors and do not necessarily reflect the views of the National Bureau of Economic Research.

NBER working papers are circulated for discussion and comment purposes. They have not been peerreviewed or been subject to the review by the NBER Board of Directors that accompanies official NBER publications.

(C) 2013 by Gordon C. McCord and Jeffrey D. Sachs. All rights reserved. Short sections of text, not to exceed two paragraphs, may be quoted without explicit permission provided that full credit, including (c) notice, is given to the source. 
Development, Structure, and Transformation: Some Evidence on Comparative Economic

Growth

Gordon C. McCord and Jeffrey D. Sachs

NBER Working Paper No. 19512

October 2013

JEL No. O1,O13,O3,O4

\begin{abstract}
We suggest that the geographical patterns of income differences across the world have deep underpinnings. We emphasize that economic development is a complex process driven by economic, political, social, and biophysical forces. Some economists have argued that the patterns reflect mainly the historical footprint of colonial rule and political evolution, and that geography's effects on development occurred exclusively through its effects on this historical institutional development. We believe that economic development has also been shaped very importantly by the biophysical and geophysical characteristics of economies. Per capita incomes differ around the world in no small part because of sharp differences across regions in the natural resource base and physical geography (e.g. distance to coast), and by the amplification of those differences through the dynamics of saving and investment. We posit that the drivers of economic development include institutions, technology, and geography, and that none of these alone is sufficient to account for the diverse patterns of global growth. We survey the relevant literature, and empirically show that a multi-causal framework helps to explain when countries achieve middle income; the distribution of economic activity around the world today; the patterns of growth between 1960 and 2010; the patterns of income per person within large economies; and the structural characteristics of the remaining countries still stuck in poverty today.
\end{abstract}

Gordon C. McCord

University of California, San Diego

School of International Relations \& Pacific Studie

9500 Gilman Drive \#0519

La Jolla, CA 92093-0519

gmccord@ucsd.edu

Jeffrey D. Sachs

The Earth Institute at Columbia University

314 Low Library

535 West 116th Street, MC 4327

New York, NY 10027

and NBER

sachs@columbia.edu 


\section{Introduction}

A map of world GDP per person (Figure 1) reminds us that the pace of economic development has varied widely and with strong geographical patterns. The countries are color-coded by quintiles of income, from dark red (the poorest) to dark blue (the richest). The high-income world includes the US and Canada, Western Europe, Australia, Japan and Korea, and a few other places (e.g. the oil-rich United Arab Emirates). Tropical Africa is the poorest region, followed by South Asia. Latin America, North Africa, and most of Southeast Asia are middle-income regions. As many have noted, there are two geographic gradients lurking in this map: from the relatively poor equator on all continents to the richer mid-to-high latitudes; and from the relatively poorer continental interiors (especially landlocked countries) to the richer coasts.

In this paper, we suggest that these geographical patterns have deep underpinnings. We emphasize that economic development is a complex process driven by economic, political, social, and biophysical forces. Some economists have argued that the patterns evidenced in Figure 1 reflect mainly the historical patterns of colonial rule and political evolution, and that geography's effects on development occurred exclusively through its effects on this historical institutional development (Acemoglu, Johnson and Robinson 2001, 2002; Easterly and Levine 2003; Rodrik Subramanian and Trebbi 2004; Acemoglu and Robinson 2012). We believe that economic development has also been shaped very importantly by the biophysical and geophysical characteristics of economies. Per capita incomes differ around the world in no small part because of sharp differences across regions in the natural resource base and physical geography (e.g. distance to coast), and by the amplification of those differences through the dynamics of saving and investment. We posit that the drivers of economic development include institutions, technology, and geography, and that none of these alone is sufficient to account for the diverse patterns of global growth. We survey the relevant literature, and empirically show that a multi-causal framework helps to explain when countries achieve middle income; the distribution of economic activity around the world today; the patterns of growth between 1960 and 2010; the patterns of income per person within large economies; and the structural characteristics of the remaining countries still stuck in poverty today.

\section{Conceptual Framework}

Our analytical starting point is that economic development involves five structural transformations of the economy:

- From low to high inputs of energy

- From traditional to modern agriculture 
- From traditional to produced knowledge

- From high to low mortality rates

- From rural to urban life

Each of these transformations is a complex process, involving primary resources (including land, energy, and labor); private capital accumulation; scientific and technical know-how; the provision of infrastructure, mainly by public entities; and the environment for business operations, including legal, regulatory, and social and cultural factors. As such, economic growth is forged by the interactions of the physical environment, cultural norms, institutions, and available technology. While some writers have exuberantly declared that one of these factors predominates over the others, it is the interaction of the environment, culture, institutions, and technology that counts.

\subsection{The case of the steam engine}

The takeoff to modern economic growth was made possible by the pivotal invention of the steam engine. Without it, or some other way to mobilize vast motive power, sustained economic growth was impossible, as humanity's long prior history had demonstrated. The harnessing of fossil fuel for mechanical power enabled England and later the world to break free of the tight binding constraints of relying on biomass for motive power. As economic historian A. E. Wrigley has cogently put it, the transition to modern economic growth depended on the transition from an "organic" energy system to a modern energy system mostly dependent on fossil fuels.

The invention and adoption of the steam engine perfectly illustrates the interplay of nature, culture, and institutions. The precondition, of course, is coal itself, and not just coal but coal that is near the Earth's surface and economically proximate to population centers. Moreover, the presence of iron ore was nearly as important, since the steam engine required an accompanying steel industry that was capable of producing the new machinery of the steam era (including the steam engines themselves and the new factory machinery that would run on those engines). Britain had both coal and iron ore, and had benefited from hundreds of years of prior experience using these resources before the steam era.

There is, of course, a cultural and institutional perspective as well. The 18th-century inventors of the steam engine, Thomas Newcomen and James Watt, were both seeking riches with their invention. They were exemplary figures in the commercial age. The invention of the engine by Newcomen and its improvement by Watt was the product of the market economy, and notably of intellectual property rights. Moreover, the early 19th-century factories that adopted the steam engine employed surplus labor (mainly women and 
children) from the countryside, a surplus that resulted from a preceding rise of agricultural productivity as the result of more scientific farming. One should add many other key factors as well, not the least of which was the scientific revolution that was rapidly gathering pace. Watt was working as an instrument maker at the University of Glasgow during the years of his development of his breakthrough invention.

Market institutions and intellectual property rights were critical to the Industrial Revolution, as Acemoglu and Robinson have recently argued in Why Nations Fail, but what we argue here is that they were not enough. Good institutions without massive and accessible coal reserves would not have been sufficient. There were no adequate primary energy substitutes, a fact confirmed by the two centuries of efforts that are still incomplete to mobilize non-fossil-fuel primary energy resources at modern industrial scale. The comparison of Britain and the Netherlands is eye opening. The Netherlands arrived earliest in history to an efficient set of economic and political institutions to underpin a modern market economy, but was overtaken by Britain in the Industrial Revolution. Britain's economically accessible coal reserves were significantly larger than those of the Netherlands and this gap played a key role in Britain's ability to pull ahead (using today's energy prices and 1820 population, Britain had around $\$ 45,000$ of coal per capita, while the Netherlands had around $\$ 8,900)$.

\subsection{Complementarities of economic transformation}

The initial takeoff to modern economic growth in England is therefore a vivid case of complementarities, including essential natural resources, key technological insights, the emergence of market-based institutions including intellectual property, and a supportive political environment. It's no accident that the takeoff to modern economic growth was a very rare event indeed, requiring the simultaneity of many developments, each with antecedents of preceding centuries. This is something like the birth of life itself. It happened just once, giving us a template of DNA and proteins that are universal in the biosphere. So too the modern industrial revolution happened just once, in 18th century England, and then it spread to the rest of the world with a similar DNA.

During the spread of industrialization during most of the 19th century, the proximity to coal was a sine qua non of industrialization. Western Europe, Australia, New Zealand, the United States, Japan, Russia, South Africa, and a few other places had it. Most of Africa and South America did not. By the end of the 19th century, the regions without coal had fallen far behind the coal-possessing world in industrialization, and many such places succumbed militarily and politically to the new heavy armaments fashioned by the coal age. During much of the 19th century, some heavily forested countries like the US and Scandinavia could rely on wood burning as an alternative to coal. In fact, wood fuel dominated coal burning worldwide 
until around 1870. Yet wood fuel cannot sustain a modern economy. The forests deplete far too rapidly, since the rate of forest growth is far below the energy flows needed in a modern industrial economy.

Later on, as transport costs plummeted with ocean steamers, railroads, and eventually the internal combustion engine (at the end of the 19th century), the close proximity to coal was no longer as decisive for industrialization. Coal could then be transported efficiently and economically in international trade. Countries without their own coal could bring in the needed energy by trading for it. Of course, they required a surplus of something to trade for the coal, and that often posed its own circular challenge. Industrialization requires coal; coal requires exports; but export success often requires preceding success of industrialization. How then to get started? The obvious answers were through the export of primary commodities, whether agriculture or minerals. Yet the development and trade of those commodities also require a considerable investment in infrastructure, including roads, ports, and power. Valuable minerals such as gold and diamonds could often justify the needed investments in transport and power. A few cash crops - such as cotton, coffee, tea, and cacao - might do the same for a limited region, but rarely at a scale to transform an entire national economy.

After about a century, the coal age slowly gave birth to the oil age. The age of oil was necessarily preceded by the age of coal since coal is far easier than oil to mine and to deploy for motive power. Until the advent of the internal combustion engine in the late 19th century, oil was used in small amounts (mainly for kerosene), and collected on the surface from oil seeps. The coal age made possible the advances in metallurgy and precision engineering to drill for oil and to burn the oil in a highly sophisticated internal combustion engine. By the early 20th century, the possession of oil, like the possession of coal before it, offered a new pathway to economic development. Oil could power the local economy and also be used to trade for coal and other goods and services from abroad.

Let us turn to the second transformation of the modern economy: agriculture. Food is the first need of life, and therefore constitutes upwards of 80 percent of the consumption basket of subsistence households. Until an economy enjoys an advance of agricultural yields beyond subsistence (typically 500kg to 1 ton of staple production per hectare), almost all of the economically active population will be scratching out an existence growing food. Food is expensive to transport, even today. Most economies, except very small ones with agricultural neighbors or very rich ones (such as desert oil states) that can afford high transport costs, rely predominantly on their own food production to meet basic needs.

Thus, a growing economy needs a breakthrough to high-productivity agriculture to release labor to nonfood activities. That in turn requires a supportive natural environment - with adequate soils, sunshine, water, animal health, and topography - and a range of manufactured inputs: improved seeds, fertilizers, irrigation where possible, and mechanical equipment for land grading, plowing, seeding, harvesting, process- 
ing, transporting, and storing farm products. The breakthrough from traditional to commercial agriculture, measured by the breakthrough of farm productivity from staple yields of 1 ton per hectare or less, to 2 tons per hectare or more, is therefore like energy, a matter of combining nature, culture, technology, market forces, and institutions.

Just as Britain and the Netherlands led in the 18th century development of market institutions and overseas commerce, they also led in the advent of scientific farming. The temperate climate, fertile soils, yearround precipitation, mixed crop and animal husbandry, and scientific outlook led to improved crop rotations, heartier livestock, and the increasing scientific use of fertilizers, eventually including the guano deposits of Chile and Peru. Britain's improved farming techniques were then transmitted abroad by 19th century settlers to other temperate-zone economies, notably the US, Canada, Australia, New Zealand, Argentina, and Uruguay. Each of these "lands of new settlement," or "Neo-Europes" in the phrase of Alfred Crosby (Germs, Seeds, and Animals, 1994), offered an ecology comparable to Britain, one that was enormously productive for Britain's (and Europe's) plant and animal species and agricultural techniques.

Agricultural improvement requires urban-rural as well as international trade, for example to import fertilizers and equipment from abroad for use in the rural areas. Yet the very feasibility of trade depends on the physical environment as well as on the built infrastructure and available transport technologies. As Adam Smith rightly emphasizes in The Wealth of Nations, sea-based trade is far cheaper than land-based trade per ton-km of freight. The open sea does not require road building and maintenance. Air shipments are prohibitively expensive even relative to land-based trade, except for very high-value-per-unit-weight commodities and for people and their precious time.

All this means that an economy's physical access to sea-based ports is crucial for economic development. As Smith famously noted:

As by means of water-carriage a more extensive market is opened to every sort of industry than what land-carriage alone can afford it, so it is upon the sea-coast, and along the banks of navigable rivers, that industry of every kind naturally begins to subdivide and improve itself, and it is frequently not till a long time after that those improvements extend themselves to the inland parts of the country. (Book I, Chapter 3, The Wealth of Nations)

Countries with easy access to sea-based trade have an enormous advantage over those without. Landlocked countries are notoriously disadvantaged, since they must not only typically pass a long overland distance to the sea, but must also cross a political boundary as well. Even if the landlocked country is connected to the ocean through a navigable river, the downstream coastal country may be less than obliging of the upstream neighbor. Here again Smith made pithy and prescient observations: 
The commerce besides which any nation can carry on by means of a river which does not break itself into any great number of branches or canals, and which runs into another territory before it reaches the sea, can never be very considerable; because it is always in the power of the nations who possess that other territory to obstruct the communication between the upper country and the sea. (Book I, Chapter 3, The Wealth of Nations)

There is also the key question of what to trade. Countries with large reserves of minerals, metals, energy reserves, or precious gems have a relatively straightforward answer: they can export their natural capital under the ground and use the proceeds to invest in human and physical capital. Thus, Botswana is transforming its diamonds under the Kalahari Desert into human capital and infrastructure. Chile is doing the same with its copper, as are the Gulf States with their oil and gas. But what becomes of countries with no such fortune under the ground? Some, like Argentina and Brazil can mobilize ample surpluses from its soils: grains, meat products, forest products, and the like.

Yet some countries lack primary energy resources, valuable minerals, or significant agricultural potential (perhaps because the ratio of arable land to population is low, soils are inadequate, or climate conditions limit the yields on agricultural production). What is their fate? For most of the 19th and 20th centuries, their fate was chronic poverty or migration. There was little that could be eked out in exports from the home economy. Migration was the only practical way to sell unskilled labor, and some of those earnings could be remitted back to the impoverished home economy. Yet migration was and remains wrenching, painful, and often a last resort, not least because of the unwillingness of developed economies to admit large numbers of unskilled workers from developing countries.

Fortunately, technological advances since the mid-20th century have ushered in a new range of development possibilities, in effect new ways to sell labor at long distances. In the 19th century, most of Northeast Asia and Southeast Asia exported agricultural and mining commodities in world markets. Hong Kong and Singapore, as the region's two entrepot centers, sold labor, financial, and port services. Starting in the 1960s, another possibility opened up: selling labor services to multinational manufacturing companies for the labor-intensive parts of the manufacturing production process. The phenomenon of long-distance offshoring was made possible by a range of breakthroughs in transportation (e.g. large containerized ships, intermodal transport), computerization (e.g. CAD/CAM processes), telecommunications (e.g. the Internet, mobile telephony, satellite transmission, and bar coding), and myriad other advances of the digital age. These advances are now allowing a few landlocked regions (e.g. Bangalore) to export labor services online, overcoming the age-old challenges of high over-land transport costs. Unfortunately, online services require relatively skilled workers, beyond the capability of most remaining impoverished landlocked regions. 
In addition to energy and agriculture, both supported by international trade, the growing modern economy must make a third fundamental transition: from traditional to produced knowledge. For roughly fifteen hundred years before the Industrial Revolution, traditional agricultural societies relied mainly on knowledge passed down from one generation to the next. While economic life was certainly not unchanged from one generation to the next - with the cruel visitations of epidemics, wars, famines, and the like - the technologies on which the agrarian economy rested seemed to be established on eternal and unchanging verities. For that reason Keynes made his famous observation in his 1930 essay "The Economic Possibilities of Our Grandchildren," that a peasant from Roman times would have felt at home in the technological milieu of pre-industrial 18th century Europe.

The reliance on slowly changing, implicit knowledge ended dramatically, decisively, and irrevocably with the Industrial Revolution. The progress of the world economy since then has depended on the systemic production of knowledge, with a complex interplay of mass literacy, public education, industrial research and development, and public investments in science and technology. The realization that innovation is the key long-term driver of development was itself an innovation, of a long line of hallowed thinkers stretching from Francis Bacon, to Condorcet, to Schumpeter, Solow and today's economists.

The central role of knowledge and human capital is now universally acknowledged. What is sometimes overlooked is the complementary process of the demographic transition. Each new generation requires a higher level of human capital investment per person than the preceding generation. This requires that parents shift along the quality-quantity tradeoff by having fewer children while investing more per child in human capital (including health, nutrition, and education). Yet the shift to few children also depends on a complementary breakthrough in child survival. It is the dramatic reduction in under-5 mortality, from around $40 \%$ of children in the pre-industrial period to below $1 \%$ in the high-income world today that makes possible the decline of the Total Fertility Rate (TFR) to 2 or below. Households have fewer children when they are confident that those children will survive. Therefore, a shift from high mortality to low mortality is a sine qua non of development; it is not only an outcome, but an input to growth. Yet Africa's extraordinary disease burden probably has its most pernicious consequences for economic growth in delaying the demographic transition to low fertility rates. (The other major consequences are in the physical development of children beset by repeated bouts of infection and chronic under-nutrition). As the cradle of many of humanity's oldest and most serious disease scourges, such as malaria, Africa has long suffered a level of disease burden and child mortality far beyond that of other regions at comparable income levels. This has caused Africa to lag in the demographic transition as well. With families of 6-8 children throughout most of rural sub-Saharan Africa (until recently), poor families have been unable to invest adequately per child in human capital.

The fifth transition is from the farms to the cities. Urbanization, we've already noted, is partly a reflection 
of advances in agriculture: with rising farm productivity, a declining proportion of the total labor force is needed to feed the population. Labor leaves the farms for work in industry and services. These sectors, in turn, benefit from the high population densities and face-to-face contacts of urban life. (Technically, they rely on reduced transactions costs and agglomeration economies). Thus, as labor is disgorged from the increasingly productive farms, the new industries and services establish themselves in the cities.

The Netherlands and Britain were precocious urbanizers in part because they were also precocious in raising farm productivity, having introduced new crop rotations including nitrogen-fixing legumes and even chemical fertilizers (notably guano and nitrates from South America) in the 18th and 19th centuries. The early 20th-century invention of industrial fertilizers (the Haber-Bosch process), improved seed breeding supported by advances in genetics, and advances in mechanization, gave further dramatic boosts to farm productivity and thereby to urbanization in the 20th century. The Green Revolution in Asian and Latin America, occasioned by high-yield seeds developed in the 1940s and 1950s, was decisive in spurring agricultural productivity in the peasant economies of the developing world after 1950, though once again, the fruits of that technological revolution came late and last to Africa for many reasons, including Africa's unique agro-ecological conditions. In any event, the Green Revolution was key to speeding urbanization in the developing world.

Yet not all depends on farm productivity. The productivity of the cities themselves is another basic determinant of the speed of the rural-to-urban transformation. Cities that are well integrated into global trade and finance are better able to support their own hinterlands with growing markets, improved inputs, more extensive infrastructure, and trade financing. Just as agricultural advances spur urbanization, so too do urban advances spur agriculture. This dynamic two-way interaction between the countryside and city produce a self-sustaining positive feedback loop when conditions are right. Cheap energy sources are vital. Public investments in infrastructure (e.g. water, sanitation, roads, ports, and power grids) are vital to support rapidly growing cities. Effective urban public health units are vital to prevent urban epidemics of cholera, yellow fever, measles, and other communicable diseases.

The key location for productive cities is the seacoast, especially at the estuary of a major river that links the port city with the hinterland as well as with world markets. The greatest cities of the world are generally blessed with a geographic advantage that enables them to look both inward and outward at the same time: New York on the Hudson River, Shanghai on the Yangtze River, London on the Thames, and so forth. When cities are themselves landlocked (far from the coast and river-based trade), such as Moscow, they may be effective political capitals, but cannot become world cities generating self-sustaining economic growth through the national economy. 


\subsection{Structural Factors of Development}

Here are some of the key lessons of these factors for the history of economic development:

- Economies need access to abundant supplies of modern energy sources, and in recent history, fossil fuels. A home supply is a huge advantage; without it, an economy must trade for its energy needs;

- Economies need to modernize their agriculture, and this depends on adding inputs to agriculture, agronomic conditions - soils, climate, water - and on the proximity of the hinterland to world markets (e.g. to be able to purchase inputs);

- Economies need to trade surplus products or services - cash crops, minerals, energy, or labor - for the commodities and technologies that they are unable to produce economically at home. The availability of such a surplus is no assured matter. If agriculture is unproductive; transport conditions are poor; and the economy lacks adequate reserves of mining resources, the real alternatives may be poverty, migration, or a harrowing combination of the two.

- Location matters enormously. Coastal locations are the best. Proximity to world markets matters. Being landlocked can be a life sentence of poverty, especially if the economy (unlike Botswana) has no high value commodities to export.

- Disease ecology matters, not only for human wellbeing, but for economic development as well. A heavy disease burden can slow or even block the demographic transition, and thereby impede the transition to a knowledge economy.

For these reasons, the relative success of economies in economic development depends not only on the quality of institutions, as economists are so fond of emphasizing, or on culture, as some economic historians and sociologists tend to favor, but also on the sheer physical realities of the national economy: its energy reserves, distance from the seacoast, distance from world markets, temperature and disease ecology, and agro-ecological determinants of crop productivity (soils, precipitation, elevation, and so forth).

Here is a simple illustration of that principle. Let us rank countries according to GDP per capita (purchasing-power adjusted), energy reserves per capita, distance from the seacoast, and malaria ecology. On each of these measures, the economies are put into quintiles, from worst (lowest) to best (highest). We consider the universe of countries with a population of at least 1 million as of 2005 .

Now, let us consider countries that are both energy poor and far from the coast. Notably, we'll first look at countries that are in the lowest two quintiles on both dimensions. There are 24 such countries, 20 of which are in sub-Saharan Africa, plus Moldova, Afghanistan, Bangladesh, and Nepal. Of these 24 countries, 21 are 
poor, that is, in the lowest income quintile; two are in the second income quintile; and only one, Botswana, is a middle-income country (in the 4th quintile). The reason for that single exception is obvious: diamonds. By contrast, among the 44 countries that are in the top three quintiles on both energy and proximity to the coast, not a single country is poor (in the lowest income quintile). Only 7 are in the second income quintile.

Consider by itself the heavy burden of energy poverty. There are 48 countries in the lowest two energy quintiles (that is, lowest two quintiles of energy reserves per capita). Of these, 28 countries, equal to $58 \%$ of the energy-poor countries, are income-poor. On the other end of the spectrum, there are 99 countries in the top three energy quintiles. Of these, only 6 , or $6.1 \%$, are income-poor. Having energy reserves is, by itself, almost a ticket out of poverty. Of the 29 highly coastal countries (i.e. those with the highest proportion of the population close to the seacoast), there is only one poor country: Haiti. Only two are in the second income quintile: the Philippines and Sri Lanka.

We note that Sub-Saharan Africa is relentlessly maligned for its poor governance, which according to most economists, accounts for its failure to develop. Yet sub-Saharan Africa ranks extremely low on nearly every structural determinant of economic development. The region is nearly devoid of coal (except for the deposits at the southern and richer tip of sub-Saharan Africa). The region's population is unusually far from the coast, far from international trade, burdened by very high tropical temperatures, and also by the uniquely heavy burden of tropical diseases.

These points are, of course, not made to claim that economic development in sub-Saharan Africa is impossible, only that it is has been harder. The region's energy, transport, and climate characteristics are serious obstacles that must be addressed through investments in technologies, infrastructure, and public health that can counteract some of the physical obstacles. Fortunately, recent hydrocarbon discoveries (e.g. in Ghana, Mozambique, and Uganda), and rapidly falling costs of photovoltaic and wind power may yet bring much of sub-Saharan Africa the low-cost modern energy supplies that it urgently needs. Improved transport and Internet connectivity can also help to overcome the long overland distances that impede African trade. The general point is that additional investments in human and physical capital are needed to compensate for geographical obstacles. Financing those countervailing investments has been a central and long-standing challenge for the region.

\section{Data}

In Figures 2-7, we present maps of key geophysical conditions that have influenced the success or failure of economic transformation. For each variable, the color scheme of the map allocates the countries by quintiles, from worst (red) to best (blue). The richest countries (in blue in Figure 1) are also the countries with the 
most fortuitous combination of structural characteristics in Figures 2-7.

\subsection{Energy}

Country-level data for coal, natural gas and petroleum reserves are from the Energy Information Administration' International Energy Statistics. The units were converted into quads; then we add to today's reserves the cumulative consumption of coal in key countries from Rutledge (2011) and Patzek and Croft (2010). Separately, we use the EIA's hydropower generation data and turned it into a "reserve stock" by multiplying (arbitrarily) by 50. The energy reserve stock is then converted from quads into dollars using prices from Rapier (2010): $\$ 1.25$ per million btu of coal (averaging $\$ 0.56$ and $\$ 2.08$ for coal types), $\$ 5.69$ per million btu for natural gas, $\$ 13.43$ for petroleum, and $\$ 26.31$ for hydropower.

Finally, we divided by country population to reach per capita figures. The result is mapped in Figures 2 and 3 .

\subsection{Distance to Major Port}

The overwhelming majority of the world's trade happens by sea, so we can use ports as hubs of trade. We choose the world's largest ports using Containerisation International's rank of the largest ports by traffic volume (226 ports), and add a port for every coastal country with population over 1 million that did not already have a port. Finally, we added Belem and Chicago, since they are important ports that open up the interiors of South and North America, respectively. Next, we calculated the distance from each land cell to the nearest port through which it trades with the world. Transport from a location to a port can happen over land, over sea, or on a navigable river or lake. However, in order to find the optimal path to a port, we need to assign relative transport costs between land and water transport. Limão and Venables (2001) use cost data on shipping a standard 40-foot container from Baltimore to different destinations around the world in 1990 , and find that an extra $1,000 \mathrm{~km}$ by sea adds $\$ 190$, whereas $1,000 \mathrm{~km}$ by land adds $\$ 1,380$. This indicates roughly a 1:7 ratio between over-sea and overland travel, which is what we use for our analysis here. Using a map of navigable lakes and rivers, each land cell is assigned a transport cost of 7 , cells over oceans are assigned a 1, and navigable lakes and rivers are assigned a transport cost of 3.5. Note that although some Arctic rivers are ocean-navigable, they are frozen over for most of the year; consequently, we imposed an artificial travel constraint for most of the Arctic to prevent the algorithm from traveling there. We assign each country the value of the cost-adjusted distance to ports from its economic center of mass (centroid weighted for the location of economic activity, using data from Nordhaus [2007]). The result is mapped in Figure 4, by quintiles. 


\subsection{Disease Ecology}

We choose each location's malaria ecology index as a proxy for the perniciousness of the ecology vis-à-vis tropical diseases. The index is an ecological index of malaria transmission strength (used elsewhere as well; see, e.g., Sachs [24]; Carstensen and Gundlach [25] for the use of a time-static version, and McCord [26] for the time-varying version). The index combines ecological factors - rainfall and temperature-with biological ones such as the human biting preference of the mosquito species that serves as the vector for the transmission of malaria (see the Appendix for more details on the construction of the index). It is worth highlighting that the index does not include any information on human population nor on mosquito abundance; both variables affect actual malaria outcomes but are endogenous to public health efforts, so they are omitted from the construction of this exogenous index. The index is mapped in Figure 5, by quintiles.

\subsection{Temperature}

Nordhaus (2007) and others have observed that high temperatures appear to be a hindrance to economic productivity. High temperatures of course affect disease ecology (e.g. intensifying the transmission of malaria) and crop productivity. The adverse effect of high temperatures on agriculture probably reaches far beyond crops, also affecting forestry, dairy production, and livestock in ways not likely captured in the crop suitability index. Beyond agriculture, temperature may directly affect human productivity and industrial processes, as has been recently suggested by Hsiang (2010) and Jones and Olken (2010). For example, high temperatures may lower human work productivity through thermal stress. At this stage, we introduce a measure of temperature without trying to disentangle all of the possible channels. We use data from the University of Delaware (Matsuura and Willmott, [2012]), and average it for all months from 1900-2010 for each grid cell. The quintiles are mapped in Figure 6. This is only a rough proxy for the effect of temperature; one could imagine different specifications being more relevant for economic productivity such as number of days above a degree threshold.

\subsection{Agriculture}

In order to estimate an area's potential for agricultural productivity, we rely on Ramankutty et al.'s (2002) agricultural suitability index, which combines data on climate (temperature and moisture availability based on the evapotranspiration ratio) and soil (soil carbon density and soil $\mathrm{pH}$ ) to model inherent suitability for crop cultivation. Importantly, this index does not measure agricultural production itself (which could be affected by local income levels and their effect on demand and affordability of inputs), but instead measures the exogenous physical determinants of agricultural productivity. We multiply the index (which runs from 
0-1) times each grid cell's land area, and aggregate the country level. Finally, we divide by population to arrive at a quality-adjusted land per capita value, and map it in Figure 7.

\subsection{Neo-Europes}

As Alfred Crosby has powerfully argued, the temperate-zone countries of the Americas (notably the US, Canada, Argentina, and Uruguay) and Oceania (Australia and New Zealand) played a unique role in global economic development. These neo-Europes, as he calls them, were the host to a massive migration of European settlers and their fauna, flora, and pathogens. What made the neo-Europes unique is that they had been long disconnected from the Old World pool of pathogens and biota. When Europeans arrived, the native settlers were killed in overwhelming numbers by Old World epidemic diseases such as smallpox. The result was a vast new territory for European settlement that was only sparsely settled by surviving native inhabitants. Europeans brought with them not only pathogens but their crops, farm animals, and agricultural systems. These new lands also had vast natural capital: fossil fuels, fertile soils, navigable rivers and ports, and an ecology and climate highly conducive to the European fauna and flora.

\section{Results and Discussion}

\subsection{Escape from Poverty and Diffusion}

The conditions that allowed for the Industrial Revolution in England - a market-friendly political environment, abundant and accessible coal, productive agriculture, and good transport conditions - were enormously favorable, perhaps unique. After England's takeoff, the first geographic pattern of cross-country income differences began to emerge through a spatial process of diffusion of Britain's industrial breakthrough. Figure 8 below plots the year in which each European country surpassed $\$ 2,000$ in income per capita (in 1990 international dollars) against the distance of the country's population-weighted centroid to London. The association is very strong; countries nearer to England began their process of economic development first in a well-defined spatial pattern. Only by the end of the 19th century or early 20th century did industrialization proceed far into Eastern Europe.

Beyond spatial proximity to England, however, other dimensions of physical geography also shaped the patterns of diffusion. Techniques for agriculture and disease control tend to diffuse within ecological zones. Therefore, Britain's breakthroughs spread first to other parts of the world in similar ecological conditions. The Neo-Europes were therefore the first non-European countries to cross the $\$ 2,000$ threshold. More generally, the timing of a country's takeoff depended on its location, access to global trade, ecology, disease 
burden, fossil fuel reserves, and productivity of agricultural land.

Figure 9 shows a global map indicating the year in which each country first crossed the $\$ 2,000$ threshold. The first countries to cross the threshold (before 1860, in dark blue) are in Western Europe, the US, Australia and New Zealand. The next group (before 1900, in light blue) includes the other neo-Europes (Argentina and Uruguay) and more countries in Western Europe. The next group (before 1940, in green) includes Eastern Europe and Russia, Venezuela, and Japan. Then come the countries of North Africa, the Middle East, and tropical South and Central America, reaching $\$ 2,000$ between 1941 and 1980. The countries of East and Southeast Asia generally pass the threshold still later, between 1981 and 2008. A group of countries in red, mainly in Africa and Central Asia, are still in a poverty trap as of 2008.

These patterns are described in regressions shown in Table 1. In these regressions, the left-hand-side variable is the year that the country first passes the $\$ 2,000$ mark. This is regressed on various structural factors: distance to London, climate, distance to port, and so forth. We find the following results.

- Countries with populations living in temperate or cold climates with no dry season (Cf and Df zones in the Koppen-Geiger classification system) passed the $\$ 2,000$ threshold an average of 27 years before countries whose people are entirely in other zones.

- Populations far from ports were also later in developing; a country whose economy-weighted centroid is $50 \%$ farther from a port will reach the $\$ 2,000$ threshold 4 years later. - Countries that gained independence 10 years later crossed the threshold 1.3 years later;

- Countries with adverse disease ecologies (proxied by malaria ecology) have taken longer to cross the threshold.

- Countries with abundant land of good quality for agriculture and countries with abundant fossil fuel reserves per capita crossed the threshold earlier (the land quality variable is only significant to a $\mathrm{p}=0.14)$.

- Countries closer to England passed the threshold earlier, with a doubling of the distance to London associated with an additional 14 years till crossing the threshold.

- The Neo-Europes crossed the threshold 69 years earlier.

\subsection{Cross-section regressions for income per capita in 2010}

We first measure the association between cross-country income per capita in 2010 and geographical and institutional variables. We find that both physical geography and institutions likely play a strong role in accounting for the cross-country patterns of wealth and poverty. 
In the first column of Table 2, we show that just two independent variables, fossil fuel reserves per capita and average distance from a port, account for $58 \%$ of the variation in cross-country per capita income! If we add hydroelectric production per capita, malaria ecology, a quality-adjusted land per capita, and average temperature, we arrive at $75 \%$ of the cross-country variation explained. (Column II). Adding in political variables (such as being a former communist economy and the degree of civil liberties) adds further to the explanatory power of the regression (Columns III \& IV).

Given that political institutions are likely endogenous to income levels, we replicate the literature's instrumental variable method for better identifying the effect of institutions on income levels. Acemoglu, Johnson and Robinson (2001) have argued that regions with a greater inflow of European migrants were more likely to create inclusive political and economic institutions. They implemented this idea by constructing a proxy for the mortality rates of early European settlers, and used their estimated settlers' mortality rate as an instrumental variable for present-day political institutions.

We have chosen instead to use the new time series in Easterly and Levine (2012) that directly measures the share of the European population in countries during the 19th century. We choose this alternative measure as our instrument for three reasons: (1) it is a more direct measure of the settler population; (2) it covers a larger group of countries; and (3) it avoids the serious measurement errors of the mortality data pointed out by Albouy (2012). Note that we extend Easterly and Levine's measures to include Europe itself (including Eastern Europe, the Baltics, and Russia), each given a score of 100 percent European. We focus our analysis on two governance variables frequently used in the literature: the Heritage Foundations' ranking of civil liberties, and the expropriation risk variable constructed by the World Bank. Table 3 shows the results. Regressions (I) - (IV) instrument for civil liberties with the 19th century European share of the population, and (V)-(VIII) instrument for expropriation risk. In all cases, first stage regressions (I, III, V, VII) show the instrument to be strongly associated with the modern-day governance variable, and the F-statistics of the first stages are all satisfactory (above 10). In the second stage, the instrumented institutional variables are always significant, but they do not obviate the importance of the geographical variables. Average distance to ports, fossils fuel reserves and quality-adjusted land per capita remain strongly associated with modern-day levels of income after controlling for institutions.

\subsection{Within-country variation of per capita income}

Next we look at the conditioning effect that geography has on the spatial distribution of income within countries. A within-country analysis permits the use of country fixed effects to absorb all national characteristics (such as institutions, for example) that might be driving income levels and that are correlated 
with cross-country geography. We use global data on economic production at the 1 degree level compiled by Nordhaus (2007), and divide by the population in the cell to get the gross cell product (GCP) per capita. We omit cells with very few people (less than one person per square $\mathrm{km}$ ) since these create distorted per capita measurements that do not reflect actual income. This leaves more than 11,000 cells across 159 countries. The results of the regression are shown below in Table 4; column (I) includes the whole world, and columns (II)-(IV) limit the sample to Brazil, China and the United States, respectively.

Column (I) shows the powerful conditioning effect that geography has on the spatial distribution of income within countries. Areas with better conditions for agriculture, that closer to ports and therefore international markets, and with less pernicious disease ecology consistently exhibit higher levels of economic activity per person. In addition, we control for the value of fossil fuel resources and mineral resources in the grid cell, which both boost that cell's economic activity. We then repeat the regression for three of the world's large countries with geographic heterogeneity. Given the much smaller sample sizes, we expect these estimates to be less precise. The distance to port variable is consistently important with a relatively constant point estimate (notably, the U.S. displays more than twice the elasticity between income per capita and distance to ports). Disease ecology is more strongly associated with income in Brazil than in China or the U.S., while land quality for agriculture is less associated to incomes in Brazil (much of the adequate land for agriculture is far inland from the country's economic centers). Despite the reduced precision of single country estimates, the pattern is the same as the global sample: land suitability for agriculture, distance to ports, disease ecology and natural resource endowments play important roles in within-country income variation.

\subsection{Cross-section regressions for income at earlier dates}

We next examine how the relationship between the key geographic variables and income per capita has changed throughout modern economic history. Using Angus Maddison's series of historic GDP per capita, we regress income in 1820,1870,1913, 1950 and 1970 on average distance to port, fuel reserves per capita, agricultural land quality, and temperature. Results are in Table 5 below. Fossil fuels are now separated into coal, gas and oil and malaria is excluded (it is strongly significant in the absence of the temperature variable, but insignificant conditional on temperature in these specifications).

The regressions were first run with all variables included for all periods, resulting in a pattern: before 1950, natural gas, oil and hydroelectric potential were not determinants of income levels. This makes sense, given that technology for widespread use of hydroelectric power, natural gas, and oil were not in place until the early- to mid-20th century. Those variables are strongly significant starting in 1950 , and at the same 
time the importance of domestic coal deposits wanes. The other geographic variables (distance to ports, land quality for agriculture, and average temperature) remain strongly correlated to variations in income levels across countries. The coefficients on temperature and land quality are rather stable; port distance, however, seems to be increasingly important over time, with the elasticity of income to port distance being four times larger in 1970 than in 1870 . This would be consistent with a globalization of the economy; a long distance from global markets becomes more pernicious as the world economy shifts from being predominantly agricultural to modern, urban, internationalized production.

Finally, in Table 6 below we employ historic estimates of per capita carbon dioxide emissions from coal as a more direct measure of coal usage in society. Not surprisingly, coal usage tracks income levels very closely; in order to solve the joint determination of income and coal emissions, we instrument coal emissions using coal reserves per capita. Results of second stage regressions are below for 1913, 1950 and 1970 (first stages available upon request, in all of them coal reserves per capita are a strong predictor of coal usage). The results robustly demonstrate coal's importance throughout the period, as well as gas, oil, and hydroelectric power's importance starting in 1950.

\subsection{Regressions for economic growth during 1960-2010}

The cross-country regressions have a major shortcoming in allowing for no lag structure between income and its underlying geographical and institutional determinants. The usual specification of income dynamics in growth theory is that income adjusts gradually to its fundamental determinants, through long-term processes of capital accumulation. If the long-term value of income per capita is given by $\mathrm{Y}^{*}$, the usual assumption is that the instantaneous change in the current level of income $\mathrm{Y}$ is determined by the proportionate gap between current income and long-term income, thus $(1 / \mathrm{Y})(\mathrm{dY} / \mathrm{dt})=\mathrm{a}+\mathrm{b} \ln \left(\mathrm{Y}^{*} / \mathrm{Y}\right)$. As pioneered by Robert Barro and his colleagues, this results in a growth regression in which the growth of $\mathrm{Y}$ over an interval of years is regressed on the fundamental determinants of $\mathrm{Y}^{*}$ and the $\log$ level of $\mathrm{Y}$ at the start of the period. Barro (2012) has recently updated these growth regressions, and we ourselves begin from his baseline specification.

Barro's basic growth regression covers the period 1960 to 2010. The long-term determinants of $Y^{*}$ include life expectancy, fertility rate, schooling, and various policy and institutional variables. The results are shown in column 1 of Table 7 below. We note that life expectancy has a strong positive effect on long-term income and that fertility has a strong negative effect. This is in line with our long-standing hypothesis that malaria has a significant negative effect on income, since we expect malaria to reduce life expectancy and to raise fertility (through the so-called replacement effect in response to child mortality). 
In column 2, we add six of our hypothesized geographical variables to this growth regression, as well as a dummy variable for Botswana to allow for the effect of its very high per capita diamond production on growth and long-term income. We find that all six of the geographical variables have the expected sign on long-term income. Four of the six (distance to port, fossil fuels per capita, hydroelectric power per capita, and malaria burden) are statistically significant. Two are not: temperature and quality-adjusted land per person. The dummy variable for Botswana is highly significant, with a growth rate of $4.5 \%$ per year above what would be expected given the other determinants of growth. In column three, we drop the two insignificant geography variables, and re-estimate the regression equation. The four remaining geographical variables are all statistically significant.

\subsection{Countries Still in Poverty in 2008}

As a final exercise, we focus on the group of countries that have yet to pass the US $\$ 2,000$ threshold, which we can think of as being in a poverty trap. Defining a simple binary variable to distinguish those countries from the rest of the world, we estimate a probit specification on the geographic variables in our study. Interestingly, the $\%$ of population living $\mathrm{Cf} \& \mathrm{Df}$ climate zones is a perfect predictor of whether a country is in a poverty trap. In other words, having a nonzero part of the population living in these climate areas is a sufficient condition for the country to not be in a poverty trap. Therefore, the marginal effect of this variable cannot be estimated in a probit model. Table 8 below shows the marginal effects of the other variables; being far from a port or being in a malarious ecological zone increases the likelihood that a country is in a poverty trap. Meanwhile, having an abundance of arable land per capita and fossil fuel reserves per capita reduces the likelihood that a country is in a poverty trap.

\section{Conclusions}

Economic development is a dynamic process requiring fundamental transformations in several spheres of the society. Starting from a traditional economy based on subsistence food production, economic growth requires a massive mobilization of energy resources, an upgrading of rural agriculture, and large-scale investments in transport, education, and human capital. The very biggest challenge of economic development lies in getting started, making the transition from a low-level equilibrium of subsistence and low saving, to an economy generating an investable surplus that can be devoted to building human capital and infrastructure.

Before the Industrial Revolution, there was no pathway to self-sustaining growth. The binding constraint lay in technology, and especially energy. The meager flows of energy that could be eked out of biomass (for wood fuels) and animal traction were not enough to raise the economy above subsistence. Indeed, Malthusian 
dynamics were evident. Increases in survival, leading to increases in population, would put great stress on the natural environment, for example the deforestation caused by increased use of wood fuels. The Industrial Revolution, and especially the advent of the steam engine, broke the hammerlock of energy.

Growth took off in England and in other places where the mix of physical, technological, and institutional conditions made it possible. Our argument is that the underlying conditions were as much biophysical and geophysical as they were institutional. Economies benefited to the extent that nature lent a strong hand. Some of the advantages included holdings of fossil fuels, proximity to ports, high quality agricultural land, and low malaria burden. Of course institutions also mattered for the functioning of the economy. Our view is that geography is a conditioning variable, neither a sole determinant of development, nor a deterministic factor. Even harsh geography can be overcome through suitable compensatory investments: roads can be built to a distant port; fossil fuels can be imported; economies can trade manufactures and services for food they do not produce; and malaria and other communicable diseases can be controlled through targeted investments in disease control.

The evidence supports this holistic and integrative view. Cross-section regressions suggest that biophysical and geophysical factors explain the timing of different countries' escape from poverty following the Industrial Revolution, as well as a considerable amount of the cross-country variation in incomes per capita today. So too do the growth equations. Finally, geographical variables continue to be strong predictors of which countries remain trapped in poverty today. We recognize that this evidence remains circumstantial, and must be bolstered by more detailed analyses at the microeconomic level. One approach for the future will be to study the inter-regional dynamics of a single country that shares similar institutions but is varied in its physical geography and resource base. 


\section{References}

[1] Acemoglu, Daron, Simon Johnson and James A. Robinson. 2001. "The Colonial Origins of Comparative Development: An Empirical Investigation.” American Economic Review 91(5): 1369-1401.

[2] Acemoglu, Daron, Simon Johnson and James A. Robinson. 2002. "Reversal of Fortune: Geography and Institutions in the Making of the Modern World Income Distribution." Quarterly Journal of Economics

[3] Acemoglu, Daron and James Robinson. 2012. Why Nations Fail: The Origins of Power, Prosperity, and Poverty. Crown Publishers: New York.

[4] Albouy, David. 2012. "The Colonial Origins of Comparative Development: An Empirical investigation: Comment," American Economic Review 102(6): 3059-3076.

[5] Barro, Robert. 2012. "Convergence and Modernization Revisited," Harvard Department of Economics, August

[6] Carstensen, Kai and Gundlach, Erich. 2006. The Primacy of Institutions Reconsidered: Direct Income Effects of Malaria Prevalence. The World Bank Economic Review, v. 20, no. 3, pp. 309-339.

[7] Crosby, Alfred W. 1994. Germs, Seeds \& Animals: Studies in Ecological History. (ME Sharpe: Armonk, NY).

[8] Easterly, William and Ross Levine. 2003. "Tropics, germs and crops: how endowments influence economic development." Journal of Monetary Economics 50: 3-39.

[9] Easterly, William and Ross Levine. 2012. "The European Origins of Economic Development," NBER Working Paper No. 18162, June.

[10] Hsiang, Solomon M. "Temperatures and cyclones strongly associated with economic production in the Caribbean and Central America." Proceedings of the National Academy of Sciences, 107, 15367-15372.

[11] Jones, B and B Olken. 2010. "Climate shocks and exports." American Economic Review Papers and Proceedings. 100:454-459.

[12] Matsuura, Kenji and Cort J. Willmott. 2012. "Terrestrial Air Temperature: 1900-2010 Gridded Monthly Time Series." Version 3.01, available at http://climate.geog.udel.edu/ climate/html_pages/Global2011/index.html

[13] Nordhaus, William (2007). 2007. "Geography and Macroeconomics: New data and new findings," Proceedings of the National Academy of Sciences, Vol. 10, no. 13, 3510-3517 
[14] Patzek, Tadeus and David Croft. 2010. "A global coal production forecast with multi-Hubbert cycle analysis," Energy 35, pp 3109-3122.

[15] Ramankutty, Navin, Jonathan A. Foley, John Norman and Kevin McSweeney. 2002. "The global distribution of cultivable lands: current patters and sensitivity to possible climate change." Global Ecology \& Biogeography 11:377-392.

[16] Rapier, Robert. "The Price of Energy," Forbes. January 26, 2010. Accessed on : http://www.forbes.com/sites/energysource/2010/01/26/the-price-of-energy/

[17] Rodrik, Dani, Arvind Subramanian and Francesco Trebbi. 2004. "Institutions Rule: The Primacy of Institutions Over Geography and Integration in Economic Development." Journal of Economic Growth 9:131-165.

[18] Rutledge, David. 2011. "Estimating Long-Term World Coal Production using Logit and Probit Transforms," International Journal of Coal Geology. 85. pp 23-33.

[19] Sachs, J.D. 2003. Institutions Don't Rule: Direct Effects of Geography on Economic Development. NBER Working Paper 9490. 
Tables and Figures

Figure 1

\section{Gross Domestic Product per capita (2010, in current US dollars)}

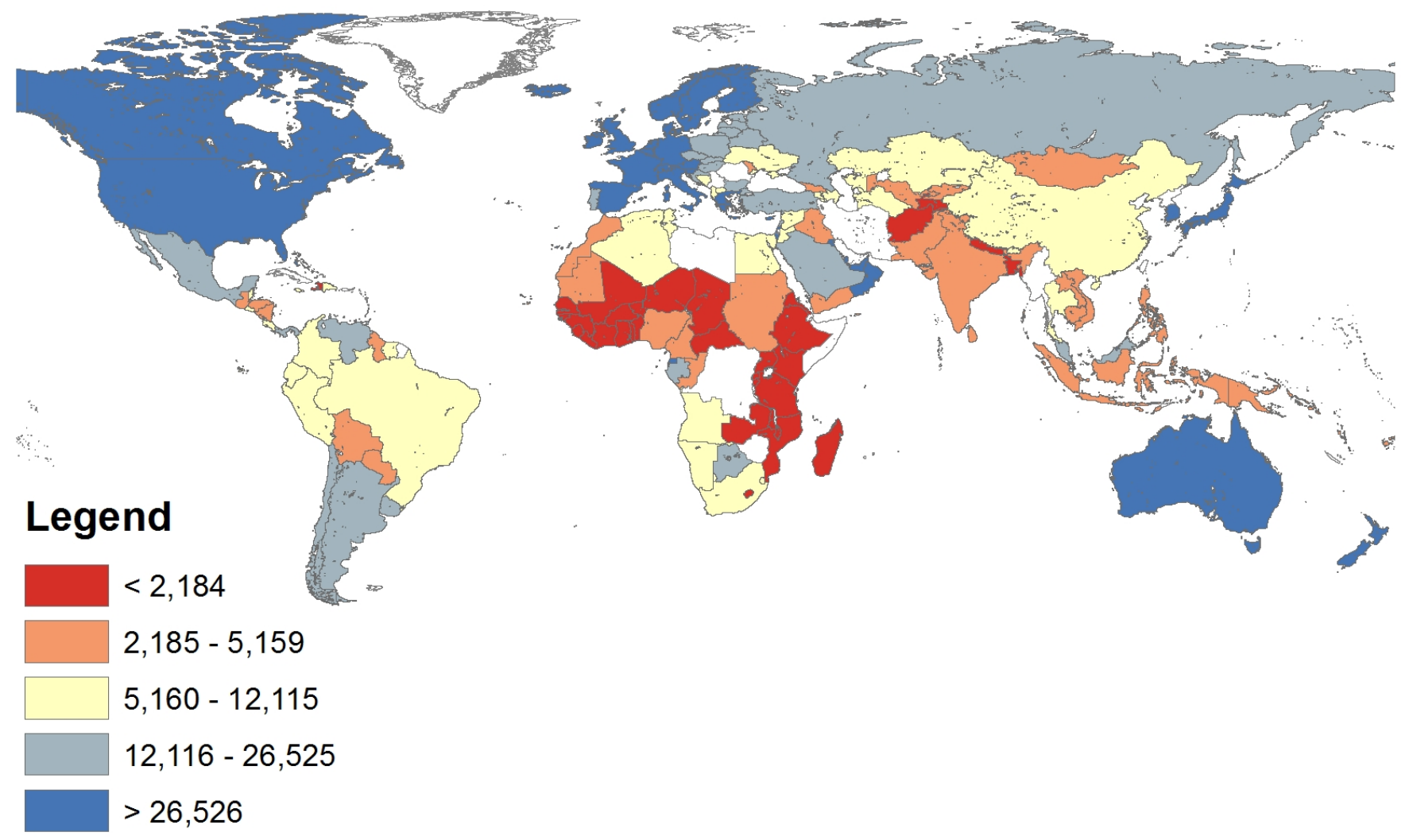

No data 
Figure 2

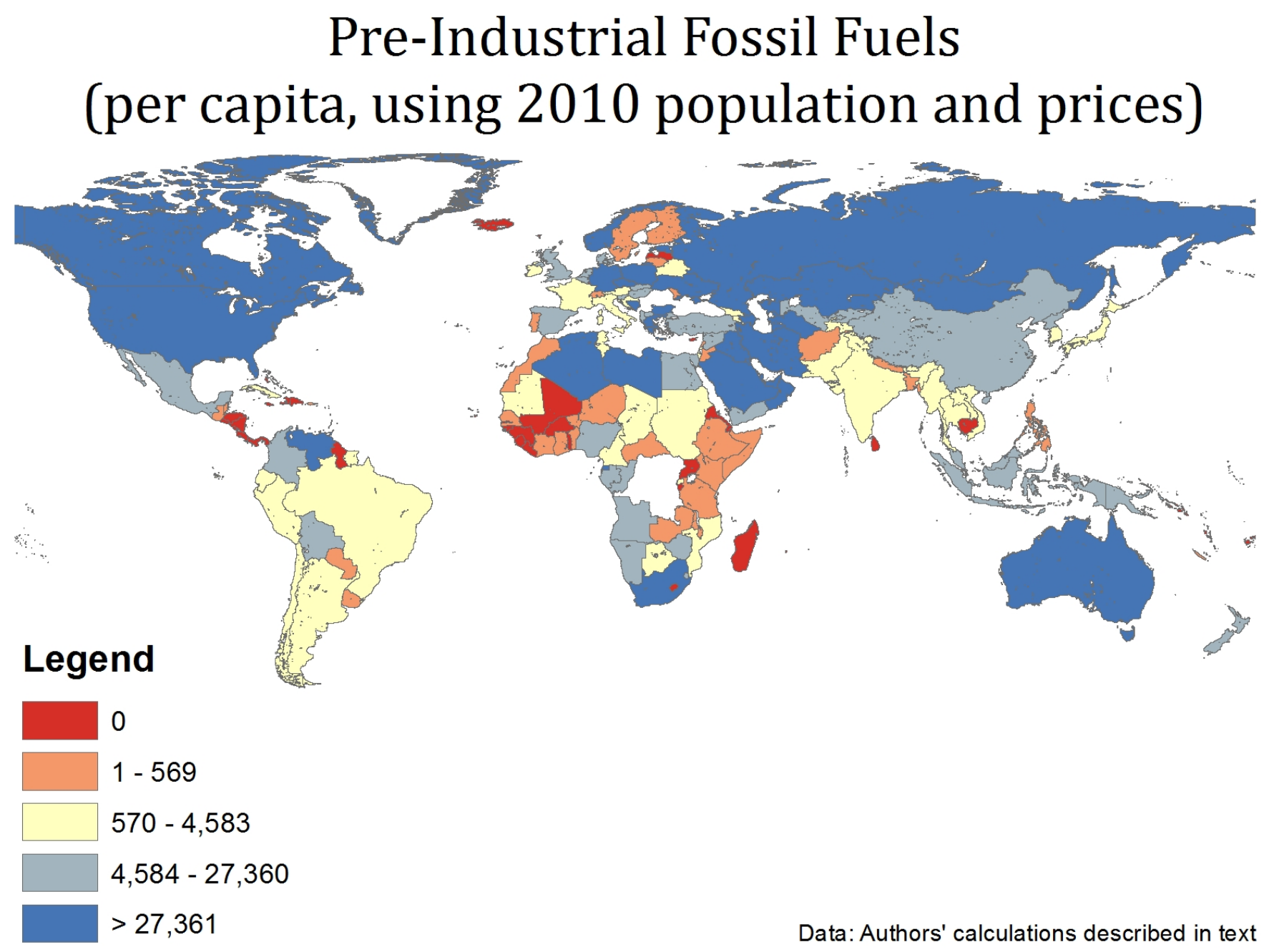


Figure 3

Hydroelectric Reserves

(\$ per capita, using 2010 population and prices)

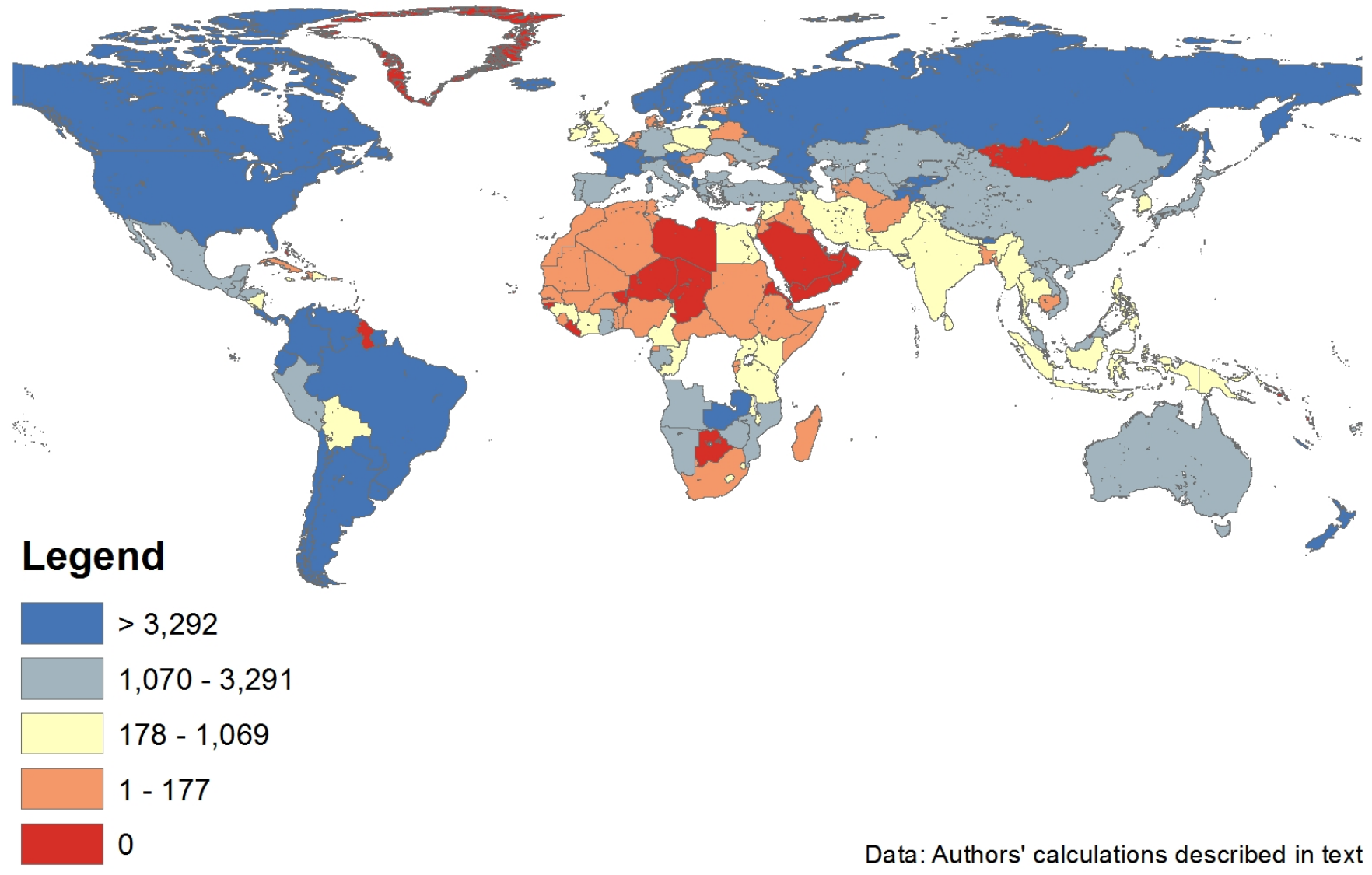


Figure 4

\section{Country's Average Distance to Major Port}

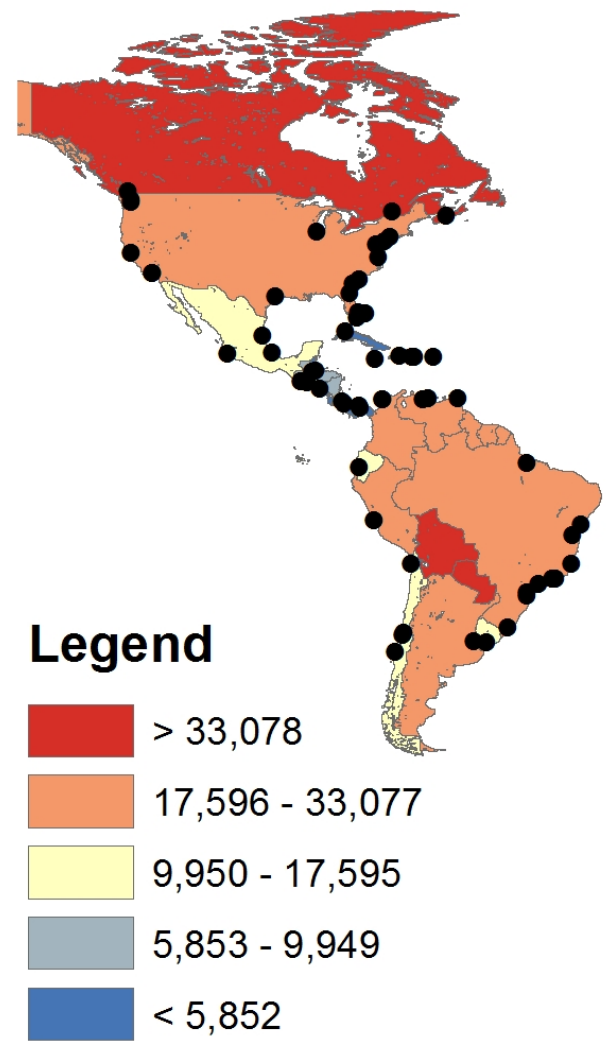

- Major Ports (by volume)

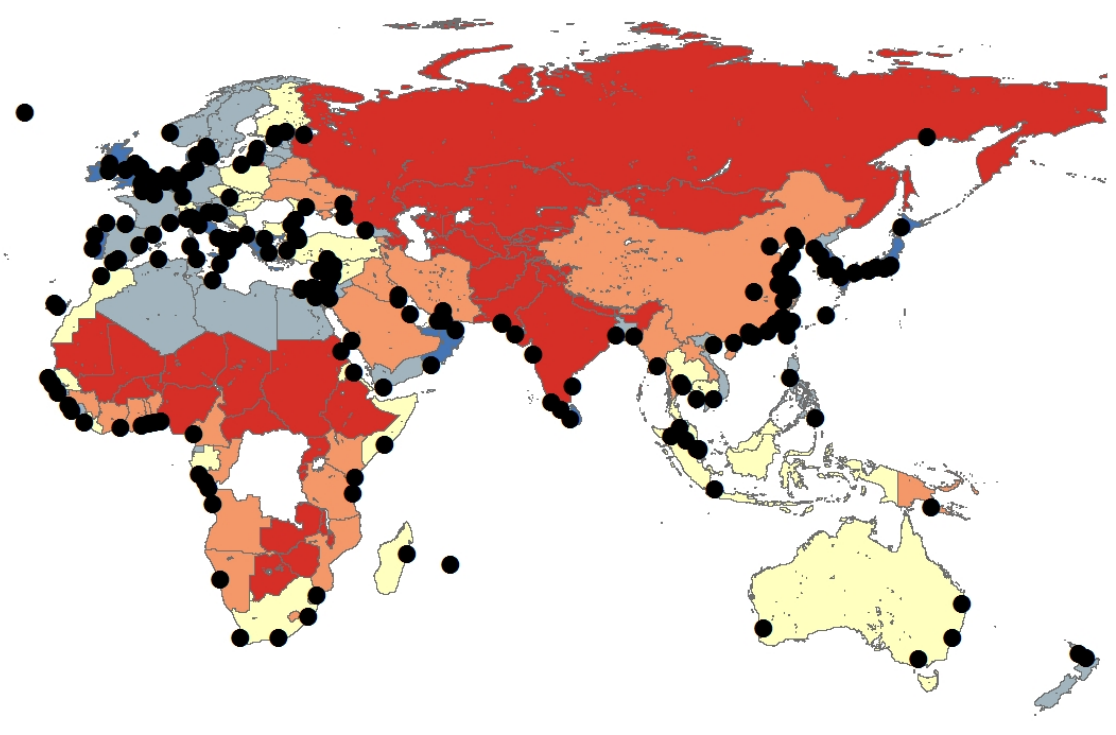

Data: Authors' calculations described in text Distance is cost-adjusted (1:7 ratio between travel over oceans or ocean-navigable rivers and travel over land) Country average weighted by fitted Gross Cell Product 
Figure 5

\section{Country's Average Malaria Ecology Index}

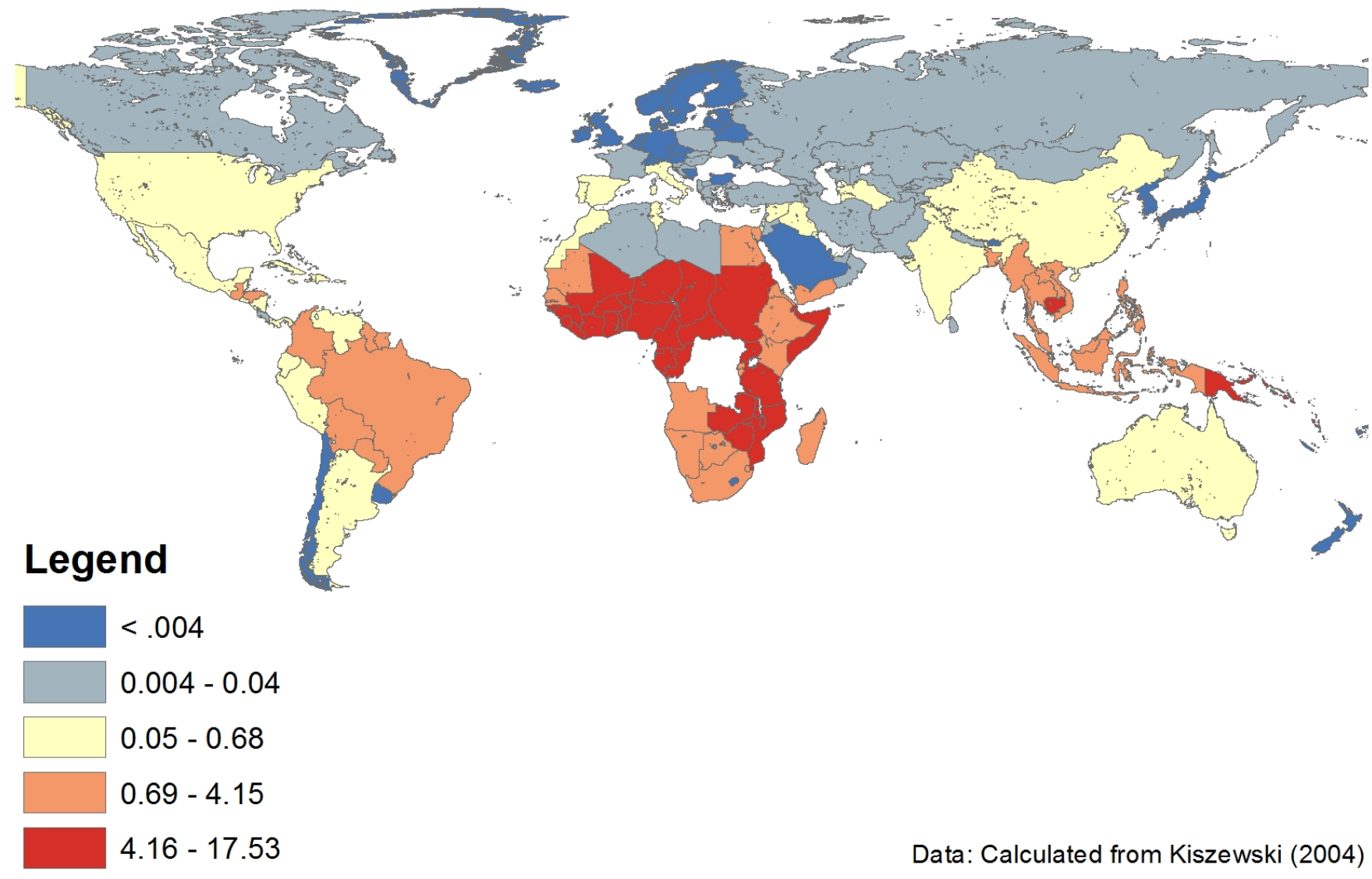


Figure 6

\section{Population-Weighted Average Temperature}

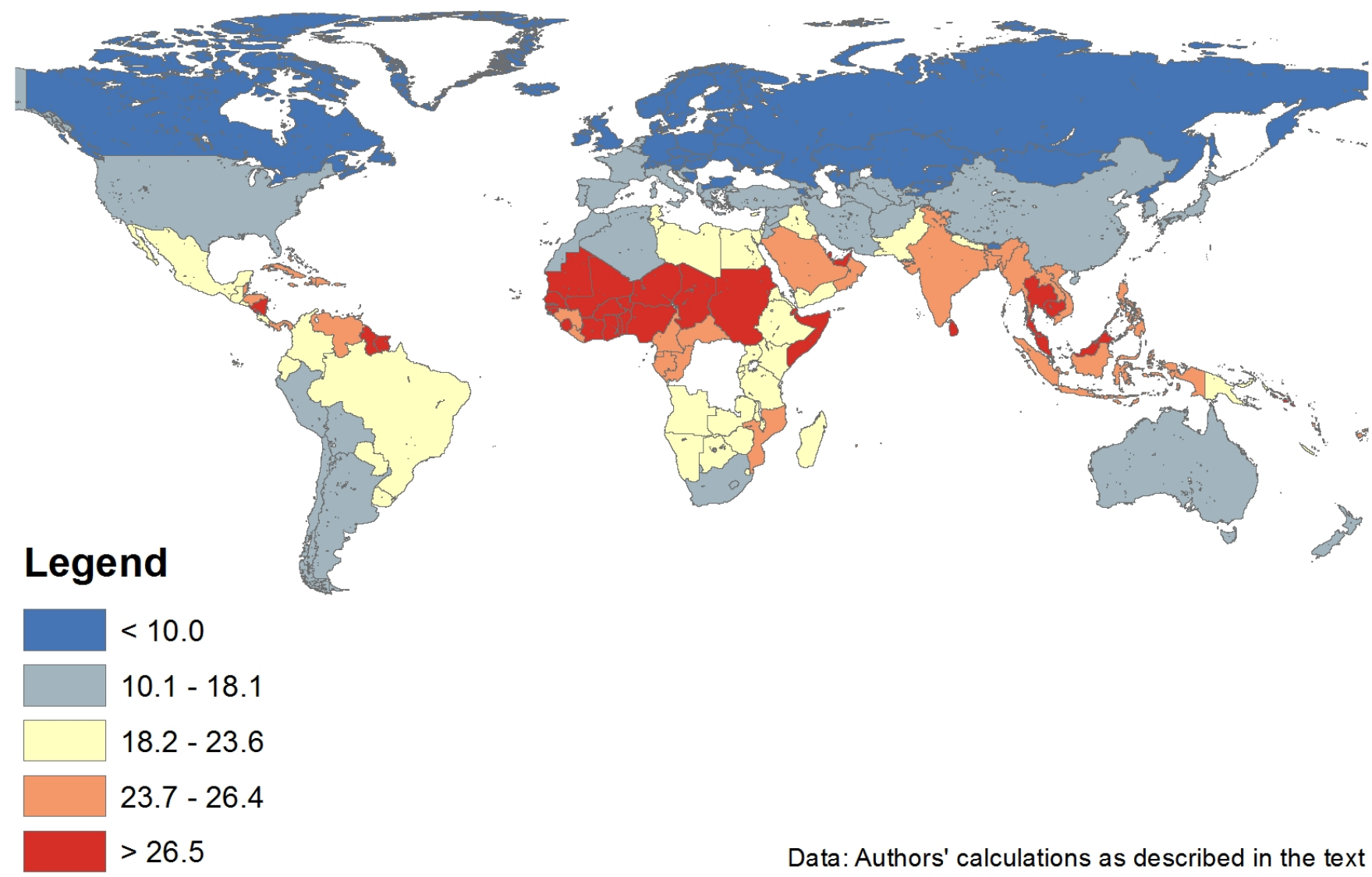


Figure 7

\section{Quality-Adjusted Land per capita}

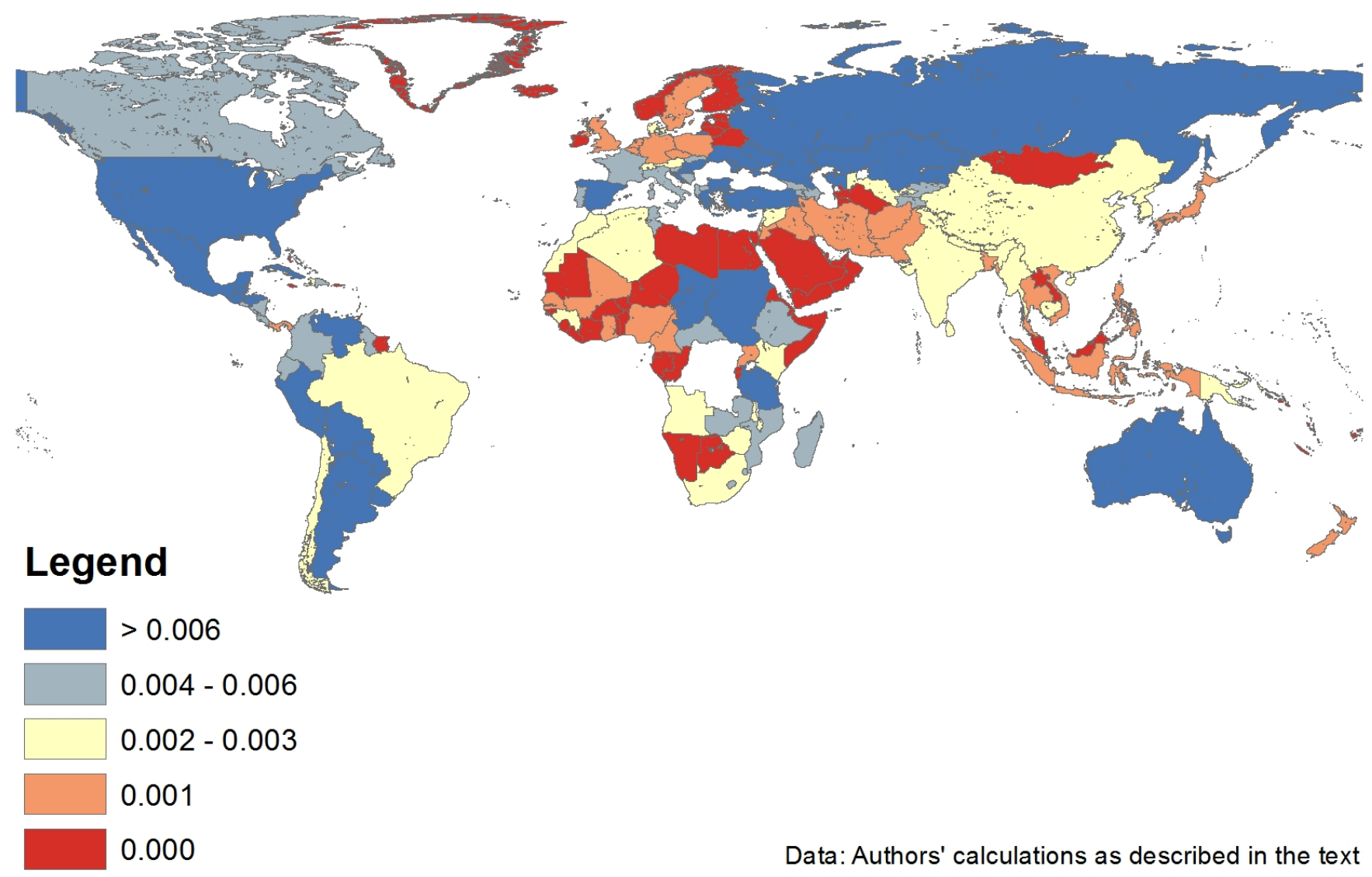




\section{Figure 8}

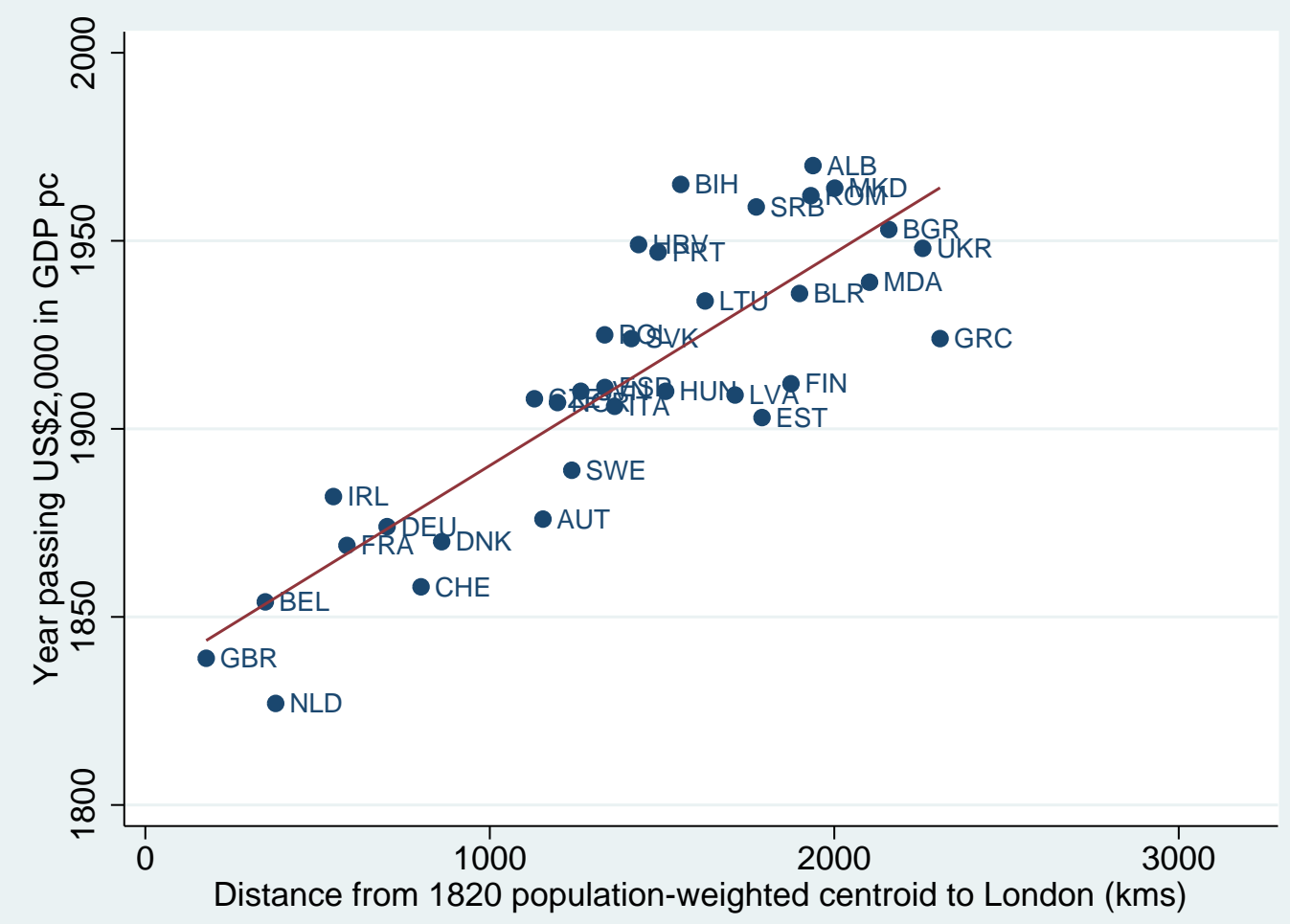


Figure 9

\section{Year (or Projected Year) Passing \$2000 Income}
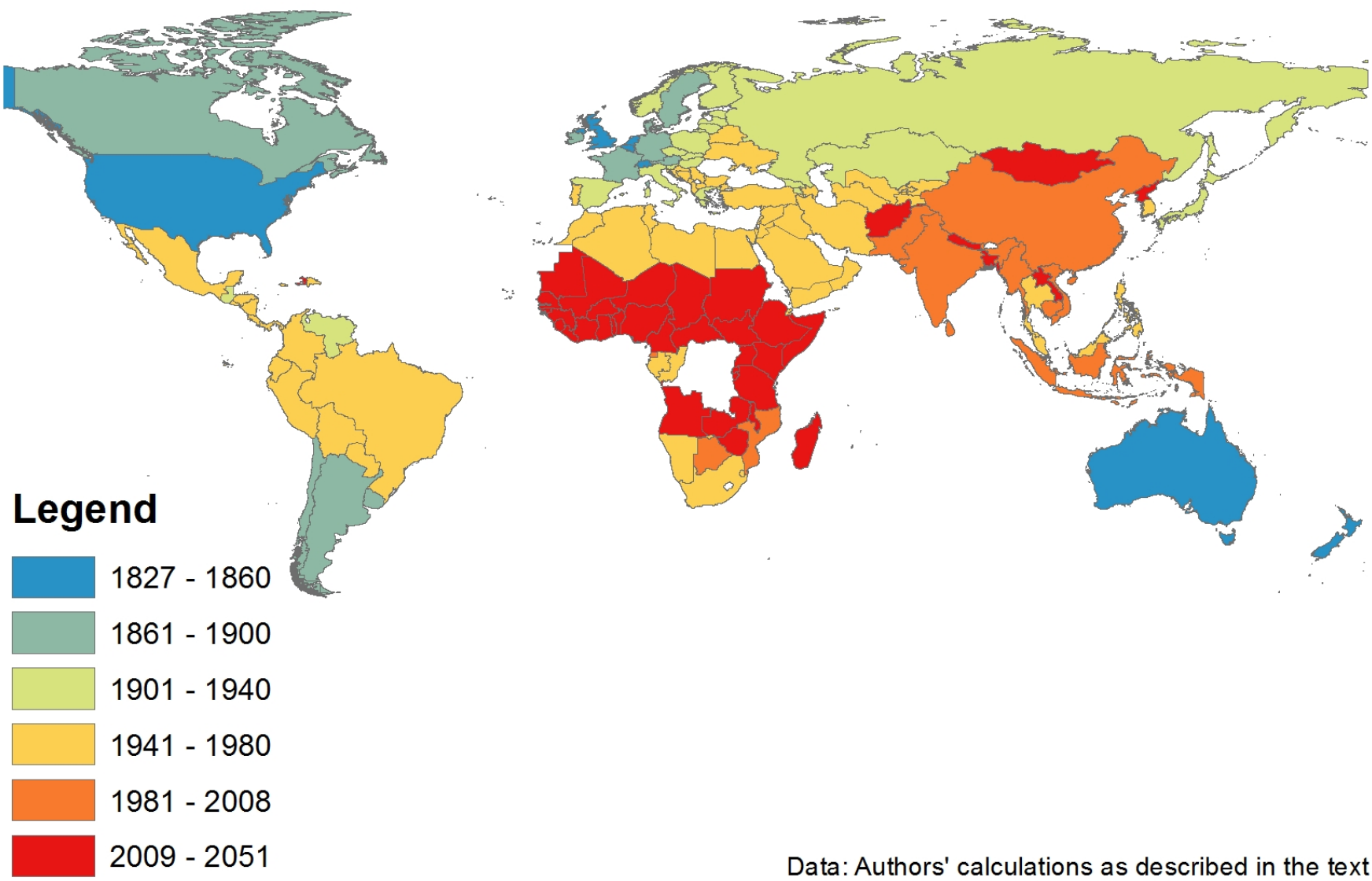

Data: Authors' calculations as described in the text 
Table 1: Timing of Escape from Poverty

\begin{tabular}{|c|c|}
\hline $\begin{array}{l}\text { Dependent Variable: } \\
\text { Independent Variables }\end{array}$ & $\begin{array}{l}\text { Year when US\$2,000 } \\
\text { Income Surpassed }\end{array}$ \\
\hline$\%$ Population in Cf \& Df Zones & $\begin{array}{l}-27.30^{* \star *} \\
(-3.54)\end{array}$ \\
\hline Years Independent since 1820 & $\begin{array}{l}-0.13^{* \pi *} \\
(-3.66)\end{array}$ \\
\hline In( Distance to Port) & $\begin{array}{c}6.95^{\star \star \star} \\
(2.73)\end{array}$ \\
\hline In( Malaria Ecology Index ) & $\begin{array}{c}10.59^{* * *} \\
(3.80)\end{array}$ \\
\hline Quality-Adjusted Land Per Capita & $\begin{array}{c}-368.51 \\
(-1.47) \\
\end{array}$ \\
\hline $\begin{array}{l}\text { In( Fossil Fuels per capita ) } \\
\text { (\$ per capita) }\end{array}$ & $\begin{array}{l}-1.69^{* \star *} \\
(-3.72)\end{array}$ \\
\hline $\begin{array}{l}\text { In( Distance to London ) } \\
\text { (from population-weighted centroid) }\end{array}$ & $\begin{array}{c}14.50^{\star \star \star *} \\
(5.16)\end{array}$ \\
\hline $\begin{array}{l}\text { Neo-Europe } \\
\text { (USA, CAN, AUS, NZ, ARG, URU) }\end{array}$ & $\begin{array}{c}-69.20^{* * *} \\
(-5.54) \\
\end{array}$ \\
\hline $\begin{aligned} \mathrm{N} & = \\
\text { Adjusted R-squared } & =\end{aligned}$ & $\begin{array}{r}140 \\
0.79\end{array}$ \\
\hline
\end{tabular}

t-statistics in parentheses; ${ }^{* t}$ indicates significant to $99 \%$ confidence

Regressions excludes countries with population below 1 million in 2005 .

Regressions include a constant, not reported 
Table 2: Cross-section for income per capita in 2010

\begin{tabular}{|c|c|c|c|c|}
\hline $\begin{array}{l}\text { Dependent Variable: } \\
\text { Independent Variables }\end{array}$ & \multicolumn{4}{|c|}{ In( GDP per capita, PPP, in 2010) } \\
\hline In( Average Distance to Port) & $\begin{array}{l}-0.77^{\star \star \star} \\
(-10.57)\end{array}$ & $\begin{array}{c}-0.63^{\star \star \star} \\
(-9.09) \\
\end{array}$ & $\begin{array}{c}-0.58^{\star \star \star *} \\
(-8.58)\end{array}$ & $\begin{array}{l}-0.44^{* * *} \\
(-6.40)\end{array}$ \\
\hline $\begin{array}{l}\text { In( Fossil Fuels per capita ) } \\
\text { (S per capita) }\end{array}$ & $\begin{array}{l}0.18^{* \star *} \\
(10.14)\end{array}$ & $\begin{array}{c}0.13^{* \star *} \\
(8.25) \\
\end{array}$ & $\begin{array}{c}0.13^{* \star *} \\
(8.71)\end{array}$ & $\begin{array}{l}0.14^{* \star *} \\
(9.76)\end{array}$ \\
\hline $\begin{array}{l}\text { In( Hydroelectric Production ) } \\
\text { (S per capita) }\end{array}$ & & $\begin{array}{c}0.07^{* \star *} \\
(3.33)\end{array}$ & $\begin{array}{c}0.06^{* * *} \\
(2.93)\end{array}$ & $\begin{array}{c}0.03 \\
(1.63)\end{array}$ \\
\hline Quality-Adjusted Land Per Capita & & $\begin{array}{l}10.42 \\
(1.55)\end{array}$ & $\begin{array}{c}11.44^{*} \\
(1.75)\end{array}$ & $\begin{array}{r}9.26 \\
(1.53)\end{array}$ \\
\hline In( Malaria Ecology Index ) & & $\begin{array}{c}-0.29^{\star * *} \\
(-3.12)\end{array}$ & $\begin{array}{c}-0.29^{* \star \star} \\
(-3.21)\end{array}$ & $\begin{array}{c}-0.38^{* \star \star} \\
(-4.48)\end{array}$ \\
\hline Population-weighted avarege temperature & & $\begin{array}{l}-0.03^{* *} \\
(-2.59)\end{array}$ & $\begin{array}{c}-0.05^{\star \star \star \star} \\
(-3.84)\end{array}$ & $\begin{array}{l}-0.02 \\
(-1.52) \\
\end{array}$ \\
\hline Botswana dummy & & $\begin{array}{c}2.23^{\star \star \star} \\
(3.41)\end{array}$ & $\begin{array}{c}2.08^{* * *} \\
(3.26)\end{array}$ & $\begin{array}{l}1.45^{\star \star} \\
(2.41)\end{array}$ \\
\hline COMECON Members & & & $\begin{array}{c}-0.53^{* * *} \\
(-3.13) \\
\end{array}$ & $\begin{array}{l}-0.39^{* *} \\
(-2.40)\end{array}$ \\
\hline $\begin{array}{l}\text { Civil Liberties in } 2005 \\
(1=\text { most; } 7 \text { = least })\end{array}$ & & & & $\begin{array}{l}-0.18^{* \star *} \\
(-4.77)\end{array}$ \\
\hline $\begin{array}{r}\mathrm{N}= \\
\text { Adjusted R-squared }=\end{array}$ & $\begin{array}{l}140 \\
0.58\end{array}$ & $\begin{array}{l}137 \\
0.75\end{array}$ & $\begin{array}{l}137 \\
0.77\end{array}$ & $\begin{array}{c}136 \\
0.80 \\
\end{array}$ \\
\hline
\end{tabular}

t-statistics in parentheses; ${ }^{* * *}$ indicates significant to $99 \%$ confidence, ${ }^{* *}$ to $95 \%$, and ${ }^{*}$ to $90 \%$.

Regressions excludes countries with population below 1 million.

Regressions include a constant, not reported

Table 3: Instrumenting for Institutions

\begin{tabular}{|c|c|c|c|c|c|c|c|c|}
\hline & (l) & (II) & (III) & (IV) & (V) & (Vl) & (VII) & (VIII) \\
\hline $\begin{array}{l}\text { Dependent Variable: } \\
\text { Independent Variables }\end{array}$ & $\begin{array}{c}\text { Civil } \\
\text { Liberties }\end{array}$ & $\begin{array}{l}\text { In( GDP per capita, } \\
\text { PPP, in 2010) }\end{array}$ & $\begin{array}{c}\text { Civil } \\
\text { Liberties }\end{array}$ & $\begin{array}{l}\text { In( GDP per capita, } \\
\text { PPP, in 2010) }\end{array}$ & $\begin{array}{c}\text { Expropriation } \\
\text { Risk }\end{array}$ & $\begin{array}{l}\text { In( GDP per capita, } \\
\text { PPP, in 2010) }\end{array}$ & $\begin{array}{l}\text { Expropriation } \\
\text { Risk }\end{array}$ & $\begin{array}{l}\text { In( GDP per capita, } \\
\text { PPP, in 2010) }\end{array}$ \\
\hline In( Average Distance to Port) & & & $\begin{array}{c}0.13 \\
(0.83)\end{array}$ & $\begin{array}{c}-0.36^{\star \star \star} \\
(-4.90)\end{array}$ & & & $\begin{array}{c}-0.13 \\
(-0.80)\end{array}$ & $\begin{array}{l}-0.28^{\star \star *} \\
(-3.33)\end{array}$ \\
\hline $\begin{array}{l}\text { In( Fossil Fuels per capita ) } \\
\text { (S per capita) }\end{array}$ & & & $\begin{array}{l}0.04 \\
(1.33)\end{array}$ & $\begin{array}{l}0.13^{* \star \star} \\
(9.00)\end{array}$ & & & $\begin{array}{c}0.10^{* \star \star} \\
(3.02)\end{array}$ & $\begin{array}{c}0.06^{* \star \star} \\
(3.41)\end{array}$ \\
\hline Quality-Adjusted Land Per Capita & & & & & & & $\begin{array}{r}-29.62 \\
(-1.21)\end{array}$ & $\begin{array}{l}20.94^{*} \\
(1.66)\end{array}$ \\
\hline In (Malaria Ecology Index) & & & $\begin{array}{c}0.1 \\
(0.60)\end{array}$ & $\begin{array}{c}-0.40^{\star \star \star *} \\
(-5.14)\end{array}$ & & & $\begin{array}{l}-0.27^{*} \\
(-1.66)\end{array}$ & $\begin{array}{c}-0.43^{* \star *} \\
(-4.70)\end{array}$ \\
\hline Botswana dummy & & & & & & & $\begin{array}{c}1.61 \\
(1.40)\end{array}$ & $\begin{array}{l}1.04^{\star} \\
(1.73)\end{array}$ \\
\hline European Share of Pop (\%) & $\begin{array}{c}-2.41^{\star \star \star *} \\
(-8.91)\end{array}$ & & $\begin{array}{c}-2.35^{\star \star \star} \\
(-7.17) \\
\end{array}$ & & $\begin{array}{c}2.86^{\star \star \star} \\
(9.96)\end{array}$ & & $\begin{array}{c}2.35^{\star \star \star} \\
(7.55)\end{array}$ & \\
\hline $\begin{array}{l}\text { Civil Liberties } \\
\text { (1 = most; } 7=\text { least) }\end{array}$ & & $\begin{array}{c}-0.79^{\star \star \star} \\
(-7.65)\end{array}$ & & $\begin{array}{c}-0.35^{\star \star \star} \\
(-5.36)\end{array}$ & & & & \\
\hline Expropriation Risk & & & & & & $\begin{array}{c}0.67^{\star \star \star} \\
(9.71) \\
\end{array}$ & & $\begin{array}{c}0.39^{\star \star \star} \\
(5.69) \\
\end{array}$ \\
\hline $\begin{array}{r}\mathrm{N}= \\
\text { First Stage F-Statistic }= \\
\text { Adjusted R-squared }=\end{array}$ & $\begin{array}{c}79.39 \\
0.38\end{array}$ & 130 & $\begin{array}{c}20.89 \\
0.39\end{array}$ & 125 & $\begin{array}{c}99.29 \\
0.48\end{array}$ & 109 & $\begin{array}{c}25.44 \\
0.59\end{array}$ & 104 \\
\hline
\end{tabular}

t-statistics in parentheses; ${ }^{* * *}$ indicates significant to $99 \%$ confidence, ${ }^{* *}$ to $95 \%$, and ${ }^{*}$ to $90 \%$.

Regressions (I), (III), (V) and (VII) are first stage regressions for (II), (N), (VI) and (VII), respectively.

Regressions excludes countries with population below 1 million.

Regressions include a constant, not reported 
Table 4: Within-Country Estimates

\begin{tabular}{|c|c|c|c|c|}
\hline $\begin{array}{l}\text { Dependent Variable: } \\
\text { Independent Variables }\end{array}$ & $\begin{array}{c}\text { In( GCP per capita, PPP, in } \\
2000)\end{array}$ & $\begin{array}{c}\text { (II) } \\
\text { In( GCP per capita, PPP, in } \\
2000)\end{array}$ & $\begin{array}{c}\text { (III) } \\
\text { In( GCP per capita, PPP, in } \\
2000)\end{array}$ & $\begin{array}{c}\text { (IV) } \\
\text { In( GCP per capita, PPP, in } \\
2000)\end{array}$ \\
\hline Land Suitability for Agriculture & $\begin{array}{l}0.75^{\star \star \star \star} \\
(5.70)\end{array}$ & $\begin{array}{c}0.01 \\
(0.07) \\
\end{array}$ & $\begin{array}{l}1.45^{\star \star \star \star} \\
(20.09)\end{array}$ & $\begin{array}{l}0.93^{\star \star \star} \\
(6.86) \\
\end{array}$ \\
\hline In( Distance to Port) & $\begin{array}{l}-0.22^{\star * \star} \\
(-3.24)\end{array}$ & $\begin{array}{l}-0.26^{\star \star \star *} \\
(-7.99) \\
\end{array}$ & $\begin{array}{l}-0.27^{\star \star \star \star} \\
(-11.41) \\
\end{array}$ & $\begin{array}{l}-0.57^{\star \star \star \star} \\
(-14.61) \\
\end{array}$ \\
\hline Malaria Ecology Index & $\begin{array}{c}-0.007^{\star \star \star *} \\
(-3.24) \\
\end{array}$ & $\begin{array}{l}-0.06^{* * *} \\
(-4.20) \\
\end{array}$ & $\begin{array}{c}0.01 \\
(0.28) \\
\end{array}$ & $\begin{array}{c}0.12 \\
(0.95) \\
\end{array}$ \\
\hline $\begin{array}{l}\text { In( Fossil Fuels per capita ) } \\
\text { (\$ per capita) }\end{array}$ & $\begin{array}{c}0.02^{* \star \star *} \\
(4.58) \\
\end{array}$ & $\begin{array}{l}0.03^{*} \\
(1.82) \\
\end{array}$ & $\begin{array}{l}0.02^{\star \star \star *} \\
(2.71)\end{array}$ & $\begin{array}{c}0.05^{\star \star \star} \\
(3.48)\end{array}$ \\
\hline $\begin{array}{l}\text { In( Mineral Value) } \\
(\$)\end{array}$ & $\begin{array}{c}0.07^{* * *} \\
(2.02) \\
\end{array}$ & $\begin{array}{r}0.16 \\
(1.17) \\
\end{array}$ & $\begin{array}{r}-0.004 \\
(-0.03) \\
\end{array}$ & $\begin{array}{l}-0.45 \\
(-1.49) \\
\end{array}$ \\
\hline Country = & All (159) & Brazil & China & United States \\
\hline$N=$ & 11288 & 576 & 941 & 891 \\
\hline Within R-squared & 0.17 & 0.26 & 0.67 & 0.23 \\
\hline
\end{tabular}

t-statistics in parentheses; ${ }^{* * *}$ indicates significant to $99 \%$ confidence, ${ }^{* *}$ to $95 \%,{ }^{*}$ to $90 \%$

Regressions exclude grid cells with a population density below 1 person per square $\mathrm{km}$

Regressions include a constant, not reported. Regression (I) includes country dummies, and clusters standard errors by country

Table 5: Historic Income per capita \& Geography

\begin{tabular}{|c|c|c|c|c|c|}
\hline \multirow{2}{*}{$\begin{array}{l}\text { Dependent Variable: } \\
\text { Independent Variables }\end{array}$} & \multicolumn{5}{|c|}{ In( GDP per capita) } \\
\hline & in 1820 & in 1870 & in 1913 & in 1950 & in 1970 \\
\hline In( Average Distance to Port) & $\begin{array}{l}-0.10 \\
(-1.42) \\
\end{array}$ & $\begin{array}{l}-0.13 \\
(-1.49) \\
\end{array}$ & $\begin{array}{l}-0.17^{\star \star} \\
(-1.67) \\
\end{array}$ & $\begin{array}{c}-0.37^{\star \star \star \star} \\
(-6.33)\end{array}$ & $\begin{array}{l}-0.44^{\star \star \star} \\
(-7.76)\end{array}$ \\
\hline $\begin{array}{l}\text { Coal per capita } \\
\text { (millions of \$ per capita) }\end{array}$ & $\begin{array}{l}-0.04 \\
(-1.12)\end{array}$ & $\begin{array}{l}0.35^{\star *} \\
(2.35)\end{array}$ & $\begin{array}{r}0.69 \\
(1.58) \\
\end{array}$ & $\begin{array}{r}1.28 \\
(1.48)\end{array}$ & $\begin{array}{l}2.23^{*} \\
(1.71)\end{array}$ \\
\hline $\begin{array}{l}\begin{array}{l}\text { Gas per capita } \\
\text { (millions of \$ per capita) }\end{array} \\
\end{array}$ & & & & $\begin{array}{c}0.12^{\star \star \star} \\
(3.53)\end{array}$ & $\begin{array}{l}0.34^{\star \star \star *} \\
(-2.87)\end{array}$ \\
\hline $\begin{array}{l}\text { In( Oil per capita) } \\
\text { (S per capita) }\end{array}$ & & & $\begin{array}{l}0.04^{* \star} \\
(2.01)\end{array}$ & $\begin{array}{c}0.08^{* \star *} \\
(6.31)\end{array}$ & $\begin{array}{c}0.10^{* * \star} \\
(7.82)\end{array}$ \\
\hline $\begin{array}{l}\text { In( Hydroelectric Production ) } \\
\text { (S per capita) }\end{array}$ & & & & $\begin{array}{r}0.07^{* \star *} \\
(-3.49)\end{array}$ & $\begin{array}{c}0.05^{\star * \star} \\
(2.70) \\
\end{array}$ \\
\hline Quality-Adjusted Land Per Capita & $\begin{array}{l}16.51 \\
(0.85)\end{array}$ & $\begin{array}{c}15.92^{\star *} \\
(2.09)\end{array}$ & $\begin{array}{c}22.76^{\star \star \star} \\
(2.70)\end{array}$ & $\begin{array}{c}21.54^{* \star} \\
(2.49)\end{array}$ & $\begin{array}{l}13.29 \\
(1.55)\end{array}$ \\
\hline Population-weighted average temperature & $\begin{array}{l}-0.03^{\star \star \star \star} \\
(-4.57) \\
\end{array}$ & $\begin{array}{c}-0.05^{\star * \star} \\
(-5.22) \\
\end{array}$ & $\begin{array}{c}-0.06^{* * *} \\
(-6.07) \\
\end{array}$ & $\begin{array}{c}-0.04^{* \star *} \\
(-4.90) \\
\end{array}$ & $\begin{array}{c}-0.06^{\star \star \star} \\
(-6.62) \\
\end{array}$ \\
\hline COMECON Members & & & & $\begin{array}{c}-0.75^{\star \star} \\
(-3.24) \\
\end{array}$ & $\begin{array}{c}-0.76^{\star \star \star} \\
(-3.33)\end{array}$ \\
\hline $\begin{array}{r}\mathrm{N}= \\
\text { Adjusted R-squared }=\end{array}$ & $\begin{array}{c}49 \\
0.38\end{array}$ & $\begin{array}{c}57 \\
0.45\end{array}$ & $\begin{array}{c}59 \\
0.55\end{array}$ & $\begin{array}{l}123 \\
0.68 \\
\end{array}$ & $\begin{array}{l}123 \\
0.72 \\
\end{array}$ \\
\hline
\end{tabular}

t-statistics in parentheses; ${ }^{* k *}$ indicates significant to $99 \%$ confidence, ${ }^{* *}$ to $95 \%$, and ${ }^{*}$ to $90 \%$.

Regressions excludes countries with population below 1 million.

Regressions include a constant, not reported 
Table 6: Instrumenting for Coal

\begin{tabular}{|c|c|c|c|}
\hline Dependent Variable: & & DP per ca & \\
\hline Independent Variables & in 1913 & in 1950 & in 1970 \\
\hline In( Average Distance to Port) & $\begin{array}{c}-0.23^{* * *} \\
(-3.22) \\
\end{array}$ & $\begin{array}{c}-0.28^{* * *} \\
(-4.73) \\
\end{array}$ & $\begin{array}{c}-0.42^{* * *} \\
(-6.66)\end{array}$ \\
\hline $\begin{array}{l}\text { Instrumented In( } \mathrm{CO} 2 \text { Emissions from Coal ) } \\
\text { (tons of carbon per capita) }\end{array}$ & $\begin{array}{l}0.94^{\star *} \\
(2.22)\end{array}$ & $\begin{array}{l}0.85^{* *} \\
(2.01)\end{array}$ & $\begin{array}{l}0.92^{\star *} \\
(2.20)\end{array}$ \\
\hline $\begin{array}{l}\text { Gas per capita } \\
\text { (millions of \$ per capita) }\end{array}$ & $\begin{array}{l}-0.20 \\
(-0.26)\end{array}$ & $\begin{array}{l}1.70^{*} \\
(1.78) \\
\end{array}$ & $\begin{array}{c}5.01^{\star \star \star \star} \\
(3.00)\end{array}$ \\
\hline $\begin{array}{l}\text { In( Oil per capita) } \\
\text { (S per capita) }\end{array}$ & $\begin{array}{r}0.03 \\
(1.15) \\
\end{array}$ & $\begin{array}{c}0.05^{\star \star \star} \\
(3.64)\end{array}$ & $\begin{array}{c}0.07^{\star * \star} \\
(4.43)\end{array}$ \\
\hline $\begin{array}{l}\text { In( Hydroelectric Production ) } \\
\text { (S per capita) }\end{array}$ & $\begin{array}{l}0.05 \\
(1.93)\end{array}$ & $\begin{array}{c}0.06^{* * *} \\
(2.84)\end{array}$ & $\begin{array}{c}0.06^{\star \star \star \star} \\
(3.25)\end{array}$ \\
\hline Quality-Adjusted Land Per Capita & $\begin{array}{c}25.62^{* * *} \\
(4.44)\end{array}$ & $\begin{array}{c}28.53^{\text {*** }} \\
(4.26)\end{array}$ & $\begin{array}{c}19.78^{\star \star \star *} \\
(2.65)\end{array}$ \\
\hline In( Malaria Ecology Index ) & $\begin{array}{l}-0.08 \\
(-0.72) \\
\end{array}$ & $\begin{array}{l}-0.03 \\
(-0.40) \\
\end{array}$ & $\begin{array}{l}0.01 \\
(0.15) \\
\end{array}$ \\
\hline Population-weighted average temperature & $\begin{array}{l}-0.02 \\
(-1.05) \\
\end{array}$ & $\begin{array}{l}-0.03^{*} \\
(-1.94) \\
\end{array}$ & $\begin{array}{c}-0.05^{* * \star} \\
(-3.39)\end{array}$ \\
\hline COMECON Members & & $\begin{array}{c}-0.59^{* \star \star} \\
(-3.04) \\
\end{array}$ & $\begin{array}{c}-0.82^{\star \star \star} \\
(-3.89)\end{array}$ \\
\hline $\begin{array}{r}\mathrm{N}= \\
\text { F-Statistic from First Stage }= \\
\text { Adjusted R-squared }=\end{array}$ & $\begin{array}{c}55 \\
4.14 \\
0.79\end{array}$ & $\begin{array}{c}106 \\
12.91 \\
0.77\end{array}$ & $\begin{array}{c}114 \\
15.19 \\
0.78\end{array}$ \\
\hline
\end{tabular}

t-statistics in parentheses; ${ }^{* * *}$ indicates significant to $99 \%$ confidence, ${ }^{* *}$ to $95 \%$, and ${ }^{*}$ to $90 \%$.

Regressions excludes countries with population below 1 million in that year

Regressions include a constant, not reported 
Table 7: Income Growth and Geography

\begin{tabular}{|c|c|c|c|}
\hline \multirow{2}{*}{$\begin{array}{l}\text { Dependent Variable: } \\
\text { Independent Variables }\end{array}$} & \multicolumn{3}{|c|}{ Annual Growth Rate of GDP per capita } \\
\hline & (i) & (ii) & (iii) \\
\hline $\log ($ lagged GDP per capita) & $\begin{array}{c}-0.0173^{\star \star \star *} \\
(-7.90)\end{array}$ & $\begin{array}{c}-0.0211^{* \star * \pi} \\
(-8.46)\end{array}$ & $\begin{array}{c}-0.0204^{* \star *} \\
(-8.73)\end{array}$ \\
\hline 1 / life expectancy at birth & $\begin{array}{c}-2.72^{\star \star \star *} \\
(-4.30)\end{array}$ & $\begin{array}{c}-1.76^{\star *} \\
(-2.41)\end{array}$ & $\begin{array}{c}-1.67^{* \star} \\
(-2.18)\end{array}$ \\
\hline $\log ($ fertility rate ) & $\begin{array}{c}-0.0307^{\star \star \star \star} \\
(-6.23)\end{array}$ & $\begin{array}{c}-0.034^{\star \star \star \star} \\
(-7.44)\end{array}$ & $\begin{array}{c}-0.034^{* * *} \\
(-7.38)\end{array}$ \\
\hline Law \& Order & $\begin{array}{c}0.0159^{* *} \\
(2.11)\end{array}$ & $\begin{array}{c}0.0096 \\
(1.31)\end{array}$ & $\begin{array}{l}0.011 \\
(1.66)\end{array}$ \\
\hline Investment Ratio & $\begin{array}{l}0.041^{\star * \star *} \\
(2.84)\end{array}$ & $\begin{array}{l}0.02^{*} \\
(1.82)\end{array}$ & $\begin{array}{l}0.02^{*} \\
(1.87)\end{array}$ \\
\hline Female school years & $\begin{array}{c}0.0035^{\star *} \\
(2.16)\end{array}$ & $\begin{array}{c}0.003^{* *} \\
(2.31)\end{array}$ & $\begin{array}{c}0.003^{\star *} \\
(2.13)\end{array}$ \\
\hline Male school years & $\begin{array}{c}-0.0037^{\star *} \\
(-2.06)\end{array}$ & $\begin{array}{c}-0.004^{\star \star *} \\
(-2.79)\end{array}$ & $\begin{array}{c}-0.004^{* * *} \\
(-2.13)\end{array}$ \\
\hline Government consumption ratio & $\begin{array}{l}-0.026 \\
(-1.02)\end{array}$ & $\begin{array}{c}-0.045^{\star *} \\
(-2.01)\end{array}$ & $\begin{array}{c}-0.048^{\star *} \\
(-2.21)\end{array}$ \\
\hline Openness ratio & $\begin{array}{c}0.0061^{* * *} \\
(2.86)\end{array}$ & $\begin{array}{c}0.012^{\star \star \star} \\
(3.34)\end{array}$ & $\begin{array}{c}0.012^{* \star *} \\
(3.30) \\
\end{array}$ \\
\hline Terms-of-trade change & $\begin{array}{l}0.101^{\star \star \star \star} \\
(3.71)\end{array}$ & $\begin{array}{l}.099^{* \star *} \\
(3.37) \\
\end{array}$ & $\begin{array}{c}.098^{\star \star \star} \\
(3.40)\end{array}$ \\
\hline Democracy indicator & $\begin{array}{c}0.039^{*} \\
(1.95)\end{array}$ & $\begin{array}{l}0.021 \\
(1.12) \\
\end{array}$ & $\begin{array}{l}0.019 \\
(1.04) \\
\end{array}$ \\
\hline Democracy squared & $\begin{array}{c}-0.039^{* *} \\
(-2.02)\end{array}$ & $\begin{array}{r}-0.021 \\
(-1.14) \\
\end{array}$ & $\begin{array}{r}-0.019 \\
(-1.08) \\
\end{array}$ \\
\hline Inflation Rate & $\begin{array}{c}-0.0198^{\star \star \star \star} \\
(-4.72)\end{array}$ & $\begin{array}{c}-0.0197^{\star \star \star \star} \\
(-4.61)\end{array}$ & $\begin{array}{c}-0.0191^{\star * *} \\
(-4.94)\end{array}$ \\
\hline In( Average Distance to Port ) & & $\begin{array}{c}-0.0012^{* \star *} \\
(-2.87)\end{array}$ & $\begin{array}{c}-0.0012^{* * \star} \\
(-2.72) \\
\end{array}$ \\
\hline $\begin{array}{l}\text { In( Fossil Fuels per capita ) } \\
\text { (\$ per capita) }\end{array}$ & & $\begin{array}{c}0.001^{\star \star * *} \\
(4.29)\end{array}$ & $\begin{array}{l}0.0011^{* \star \star \star} \\
(4.13)\end{array}$ \\
\hline $\begin{array}{l}\text { In( Hydroelectric Production ) } \\
\text { (S per capita) }\end{array}$ & & $\begin{array}{c}0.0011^{* \star \star} \\
(2.82)\end{array}$ & $\begin{array}{c}0.0012^{* * *} \\
(3.45)\end{array}$ \\
\hline Quality-Adjusted Land Per Capita & & $\begin{array}{l}0.105 \\
(0.89)\end{array}$ & \\
\hline In( Malaria Ecology Index ) & & $\begin{array}{l}-0.004^{* \star} \\
(-2.44)\end{array}$ & $\begin{array}{l}-0.005^{* *} \\
(-2.88)\end{array}$ \\
\hline Population-weighted avarege temperature & & $\begin{array}{c}-0.0003 \\
(-1.00)\end{array}$ & \\
\hline Botswana dummy & & $\begin{array}{c}0.045^{\star \star \star *} \\
(9.49) \\
\end{array}$ & $\begin{array}{c}0.045^{\star \star \star} \\
(9.67) \\
\end{array}$ \\
\hline$N=$ & 774 & 756 & 756 \\
\hline Countries $=$ & 80 & 78 & 78 \\
\hline Adjusted R-squared = & 0.33 & 0.35 & 0.35 \\
\hline
\end{tabular}

t-statistics in parentheses; *** indicates significant to $99 \%$ confidence, ${ }^{* *}$ to $95 \%$, and * to $90 \%$.

Data are broken up into 5-year intervals starting in 1960-1965 through 2010.

Regressions include a constant and time dummies, not reported. 
Table 8: Probit Specification on Poverty Trap

\begin{tabular}{|c|c|}
\hline $\begin{array}{l}\text { Dependent Variable: } \\
\text { Independent Variables }\end{array}$ & $=1$ if $Y(2008)<2000$ \\
\hline$\%$ Population in Cf \& Df Zones & - \\
\hline In( Distance to Port) & $\begin{array}{l}0.14^{\star \star \star *} \\
(3.75) \\
\end{array}$ \\
\hline In( Malaria Ecology Index ) & $\begin{array}{c}0.12^{\star \star \star *} \\
(4.53)\end{array}$ \\
\hline Quality-Adjusted Land Per Capita & $\begin{array}{l}-17.5^{\star \star} \\
(-2.37) \\
\end{array}$ \\
\hline $\begin{array}{l}\text { In(Fossil Fuels per capita ) } \\
\text { (S per capita) }\end{array}$ & $\begin{array}{l}-0.03^{\star * \star} \\
(-3.83) \\
\end{array}$ \\
\hline$N=$ & 142 \\
\hline Pseudo R-squared = & 0.64 \\
\hline
\end{tabular}

z-statistics in parentheses; ${ }^{* * z}$ indicates significant to $99 \%$ confidence, ${ }^{* *}$ to $95 \%$

Regressions excludes countries with population below 1 million in 2005 .

Regressions include a constant, not reported 